\title{
Sedimentation in the East Branch Mahoning Creek Basin, Clearfield and Jefferson Counties, Pennsylvania, June 1979 to June 1980
}

U.S. Geological Survey Water-Resources Investigations 81-69






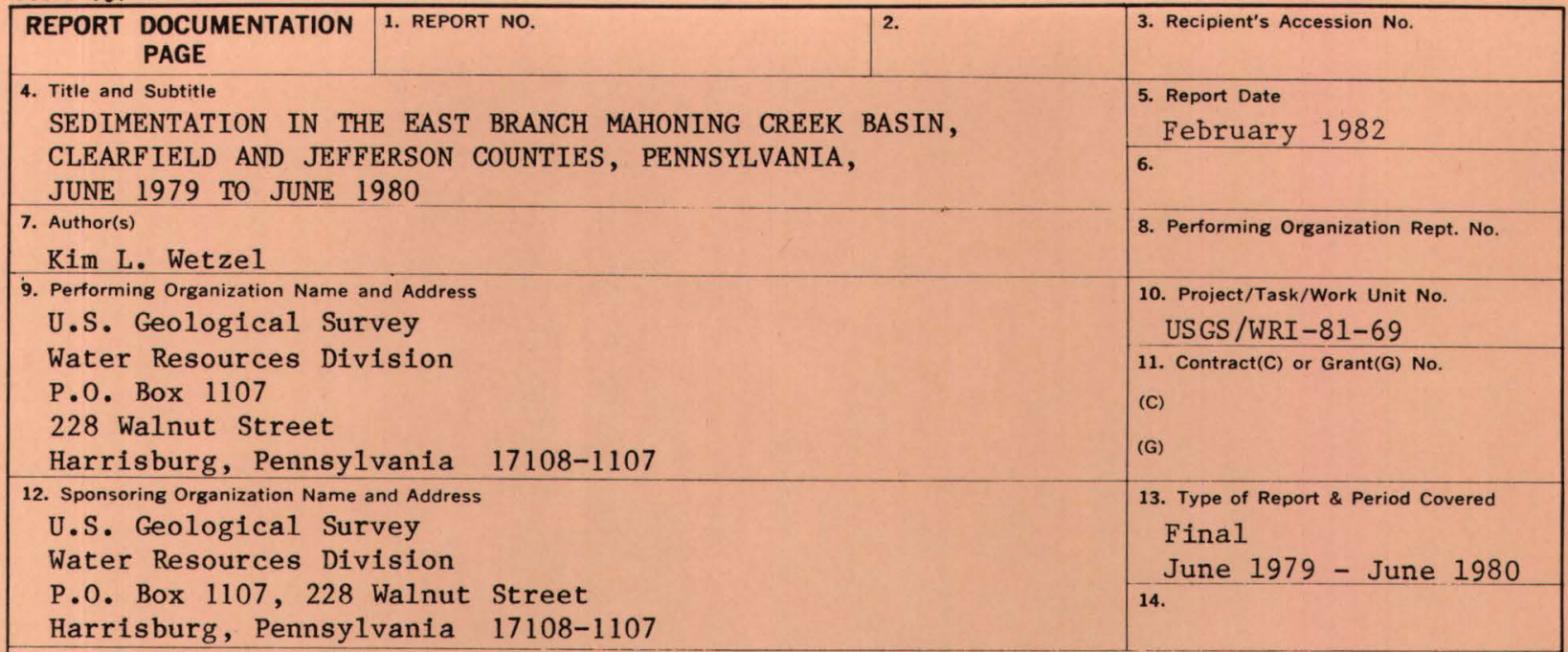

15. Supplementary Notes

Prepared in cooperation with Bureau of Mining and Reclamation, Pennsylvania Department of Environmental Resources

16. Abstract (Limit: 200 words)

Parts of the East Branch Mahoning Creek basin, a forested area of 29.6 square miles in west-central Pennsylvania, are disturbed by farming, surface mining, unpaved haul roads, eroding reclaimed areas, and logging. Streamflow was measured and water samples collected at a site upstream from the mouth from June 1979 to June 1980 during base flow and storm periods to evaluate sediment discharges. An additional site on a tributary draining mostly farmland was sampled from December 1979 to June 1980. Samples were analyzed for suspended sediment, turbidity, and specific conductance. Daily mean suspended-sediment concentrations and discharges were computed.

From June 1979 to June $1980,3,570$ tons of suspended sediment was transported from the basin. This was an average yield of 121 tons per square mile per year. From December 1979 to June 1980, a tributary draining 2.21 square miles of a predominantly agricultural area discharged 328 tons of sediment which was 12 percent of the sediment load transported from the entire basin.

Month1y sediment discharges averaged 298 tons and ranged from 32 tons in July to 1,250 tons in March. The highest daily mean suspended-sediment concentration was 712 milligrams per liter on June 8, 1980. On that date, 267 tons of sediment was discharged from the basin.

17. Document Analysis a. Descriptors

*Sediment, *surface mining, *water discharge, *rainfall, *sediment concentration, sediment yield, sediment control, erosion control

b. Identifiers/Open-Ended Terms

East Branch Mahoning Creek, Beaver Run, Clearfield County, Jefferson County

c. COSATI Field/Group

18. Availability Statement

No restriction on distribution

(See ANSI-Z39.18)

See Instructions on Reverse

\begin{tabular}{|l|l|}
\hline $\begin{array}{l}\text { 19. Security Class (This Report) } \\
\text { UNCLASS IF IED }\end{array}$ & $\begin{array}{c}\text { 21. No. of Pages } \\
34\end{array}$ \\
\hline $\begin{array}{l}\text { 20. Security Class (This Page) } \\
\text { UNCLASS IF IED }\end{array}$ & 22. Price \\
\hline
\end{tabular}

OPTIONAL FORM 272 (4-77) (Formerly NTIS-35)

Department of Commerce 
SEDIMENTATION IN THE EAST BRANCH MAHONING CREEK BASIN, CLEARFIELD AND JEFFERSON COUNTIES, PENNSYLVANIA, JUNE 1979 TO JUNE 1980

By Kim L. Wetze1

U.S. GEOLOGICAL SURVEY

Water-Resources Investigations 81-69

Prepared in cooperation with the Pennsylvania Department of Environmental Resources, Bureau of Mining and Reclamation

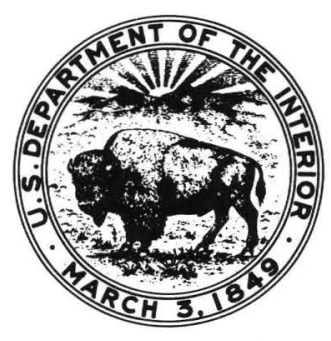


UNITED STATES DEPARTMENT OF THE INTERIOR

JAMES G. WATT, Secretary

GEOLOGICAL SURVEY

Dallas L. Peck, Director

For additional information write to:

U.S. Geological Survey 4 th Floor, Federal Building

P. 0. Box 1107

Harrisburg, Pennsylvania 17108 


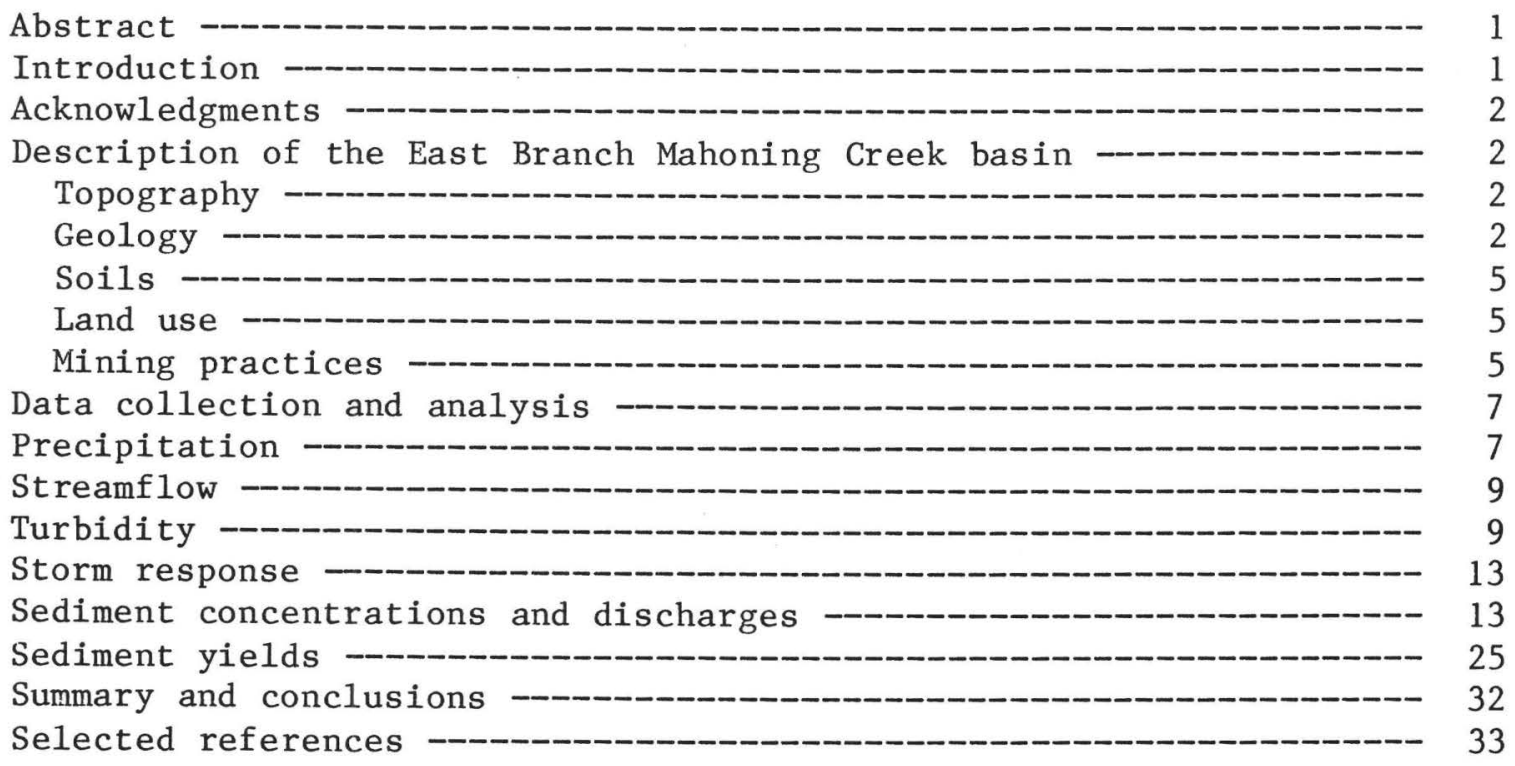

ILLUSTRATIONS

Figure 1.--Location map of the East Branch Mahoning Creek basin ---- 3

2.--Longitudinal profiles of streams in the East Branch

Mahoning Creek basin - 4

3.--Photograph showing contour mining in the East Branch

Mahoning Creek basin -_-_-_-

4-12.--Graphs showing:

4.--Plot of turbidity and suspended-sediment concentrations at site 1 , East Branch Mahoning

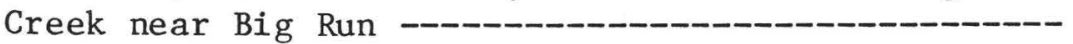

5.--Plot of turbidity and suspended-sediment concentrations at site 2, Beaver Run near Troutville --------------------------------

6.--Variations of constituents at site 2, Beaver Run near Troutville during the May 12-14 storm -------------

7.--Variations of constituents at site 1, East Branch Mahoning Creek near Big Run during the May 12-14 storm -- - - - - - - - - - -

8.--Relation between suspended-sediment discharge and streamflow, East Branch Mahoning Creek near Big Run ----------------

9.--Comparison of sediment-transport curves for Driftwood
Branch Sinnemahoning and East Branch Mahoning Creeks --_---_-_-_-_-_-_-

10.--Comparison of sediment-transport curves for Marsh and East Branch Mahoning Creeks - 
Figure 11.--Comparison of sediment-transport curves for Wilson and East Branch Mahoning Creeks - 30 12.--Comparison of sediment-transport curves for Pequea and East Branch Mahoning Creeks

\section{TABLES}

Table 1.--Month1y precipitation, in inches

2.--Precipitation and runoff, June 1979 to June 1980

3.--Daily mean water-weighted concentrations and discharges -

4.--Frequency distribution of suspended-sediment concentrations of selected streams in Pennsylvania -

5.--Summary of average annual sediment yields at selected sites in Pennsylvania

FACTORS FOR CONVERTING INCH-POUND UNITS TO

INTERNATIONAL SYSTEM UNITS (SI)

\begin{tabular}{|c|c|c|}
\hline Multiply inch-pound unit & By & To obtain SI (metric) units \\
\hline mile (mi) & 1.609 & kilometer $(\mathrm{km})$ \\
\hline acre & 4,407 . & square meters $\left(\mathrm{m}^{2}\right)$ \\
\hline square mile $\left(\mathrm{mi}^{2}\right)$ & 2.59 & square kilometers $\left(\mathrm{km}^{2}\right)$ \\
\hline $\begin{array}{l}\text { cubic foot per second } \\
\left(\mathrm{ft}^{3} / \mathrm{s}\right)\end{array}$ & 0.02832 & cubic meter per second $\left(\mathrm{m}^{3} / \mathrm{s}\right)$ \\
\hline ton (short) & 0.9072 & metric ton \\
\hline $\begin{array}{l}\text { ton per square mile } \\
\left(\operatorname{ton} / \mathrm{mi}^{2}\right)\end{array}$ & 0.3502 & metric ton per square kilometer \\
\hline $\begin{array}{l}\text { cubic foot per second } \\
\text { per square mile } \\
\left(\mathrm{ft}^{3} / \mathrm{s}\right) / \mathrm{mi}^{2}\end{array}$ & 0.0109 & $\begin{array}{l}\text { cubic meter per second per } \\
\text { square kilometer }\left(\mathrm{m}^{3} / \mathrm{s}\right) / \mathrm{km}^{2}\end{array}$ \\
\hline
\end{tabular}


SEDIMENTATION IN THE EAST BRANCH MAHONING CREEK BASIN.

CLEARFIELD AND JEFFERSON COUNTIES, PENNSYLVANIA,

JUNE 1979 TO JUNE 1980

By Kim L. Wetze1

\begin{abstract}
Parts of the East Branch Mahoning Creek basin, a forested area of 29.6 square miles in west-central Pennsylvania, are disturbed by farming, surface mining, unpaved haul roads, eroding reclaimed areas, and logging. Streamflow was measured and water samples collected at a site upstream from the mouth from June 1979 to June 1980 during base flow and storm periods to evaluate sediment discharges. An additional site on a tributary draining mostly farmland was sampled from December 1979 to June 1980. Samples were analyzed for suspended sediment, turbidity, and specific conductance. Daily mean suspended-sediment concentrations and discharges were computed.
\end{abstract}

From June 1979 to June 1980, 3,570 tons of suspended sediment was transported from the basin. This was an average yield of 121 tons per square mile per year. From December 1979 to June 1980, a tributary draining 2.21 square miles of a predominantly agricultural area discharged 328 tons of sediment which was 12 percent of the sediment load transported from the entire basin.

Monthly sediment discharges averaged 298 tons and ranged from 32 tons in July to 1,250 tons in March. The highest daily mean suspended-sediment concentration was 712 milligrams per liter on June 8, 1980. On that date, 267 tons of sediment was discharged from the basin.

\title{
INTRODUCTION
}

Because of the increased demand for low-sulfur coal, the Bureau of Mining and Reclamation (BMR), Pennsylvania Department of Environmental Resources, has issued many surface-mining permits in the East Branch Mahoning Creek basin. Recently, BMR has determined that erosion and sedimentation control facilities on mining sites have been inadequate. This is of particular concern because the stream is used as a public water supply.

The U.S. Geological Survey and Bureau of Mining and Reclamation are cooperating in a study to measure sediment discharges in the East Branch Mahoning Creek during installation of erosion and sedimentation controls by the surface miners. BMR will determine what level of mining activity the basin can sustain with minimal impact on water quality. 
Sediment discharges are being measured from two sites in the basin. Site 1, East Branch Mahoning Creek near Big Run, measures the amount of sediment discharged from the entire basin. A variety of land uses, including surface mining, are represented in the basin. Site 2, Beaver Run near Troutville, measures the sediment discharged from a subbasin, a predominant1y agricultural area. There is no surface mining in the subbasin. Data from the two sites can be compared to determine any differences in sedimentation characteristics that may be attributed to land use.

This report contains the findings of the first full year of data collected as part of a 3-year study.

\section{ACKNOWLEDGMENTS}

The cooperation and field assistance of personnel of the West Penr Water Company, Big Run, is gratefully acknowledged.

\section{DESCRIPTION OF THE EAST BRANCH MAHONING CREEK BASIN}

East Branch Mahoning Creek basin (fig. 1) is in the Pittsburgh Plateaus section of the Allegheny province of west-central Pennsylvania (Pennsylvania Department of Environmental Resources, 1980), 5.5 mi south of DuBois. The area of the basin upstream from the gaging station is $29.6 \mathrm{mi}^{2}$ in Clearfield and Jefferson Counties; about 60 percent of the basin is forested. One small village, Troutville, is on the northern basin boundary.

The Beaver Run subbasin, $2.21 \mathrm{mi}^{2}$, lies at the northwest edge of the East Branch Mahoning Creek basin; 60 to 70 percent is used for farming.

\section{Topography}

The East Branch Mahoning Creek basin is $9.5 \mathrm{mi}$ long and $4.0 \mathrm{mi}$ wide and has a typical dentritic drainage pattern. Three major tributaries flow into East Branch Mahoning Creek upstream from the gaging station. Altitudes range from $1,320 \mathrm{ft}$ above sea level at site 1 to the highest point of $2,266 \mathrm{ft}$ in the headwaters of Laurel Run.

Profiles of the main channel and its tributaries are plotted in figure 2. Gradients of the two tributaries, Laurel Run and Beech Run, are steep and similar in general appearance. Beaver Run, which drains an area of farmland, has a more gentle slope that resembles much of the main stem East Branch Mahoning Creek.

\section{Geology}

The East Branch Mahoning Creek basin is underlajin by formations of the Allegheny Group and the overlying Conemaugh Group of Pennsylvanian age (Pennsylvania Department of Environmental Resources, 1980). The Conemaugh Group consists primarily of red and gray shale and siltstone with interbeds of sandstone. Coal and limestone beds occur, but are thin and laterally discontinuous. The Allegheny Group contains several thick and extensive coal beds separated by shales, sandstones, limestones, and clay. 


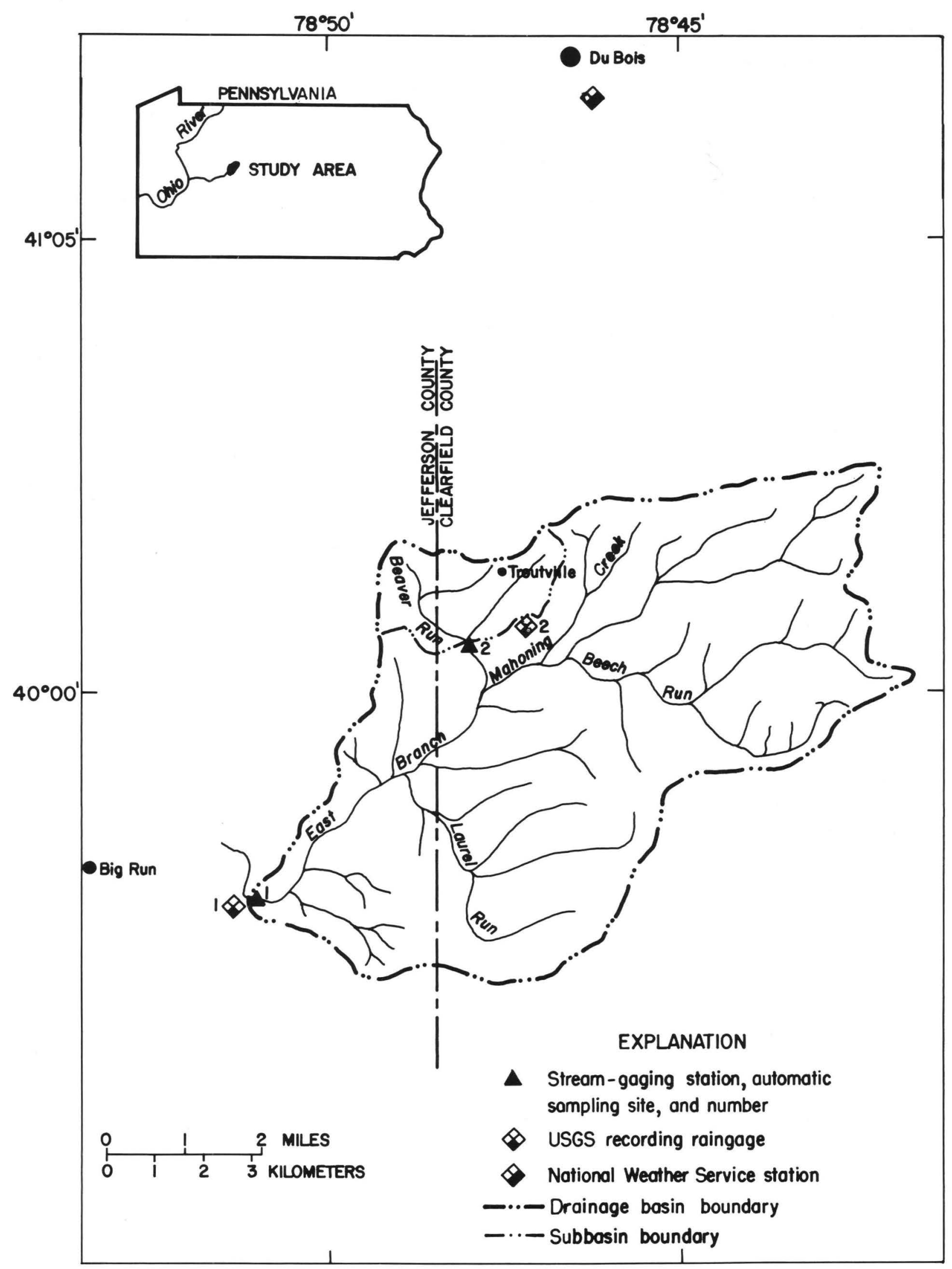

Figure 1.--East Branch Mahoning Creek basin. 


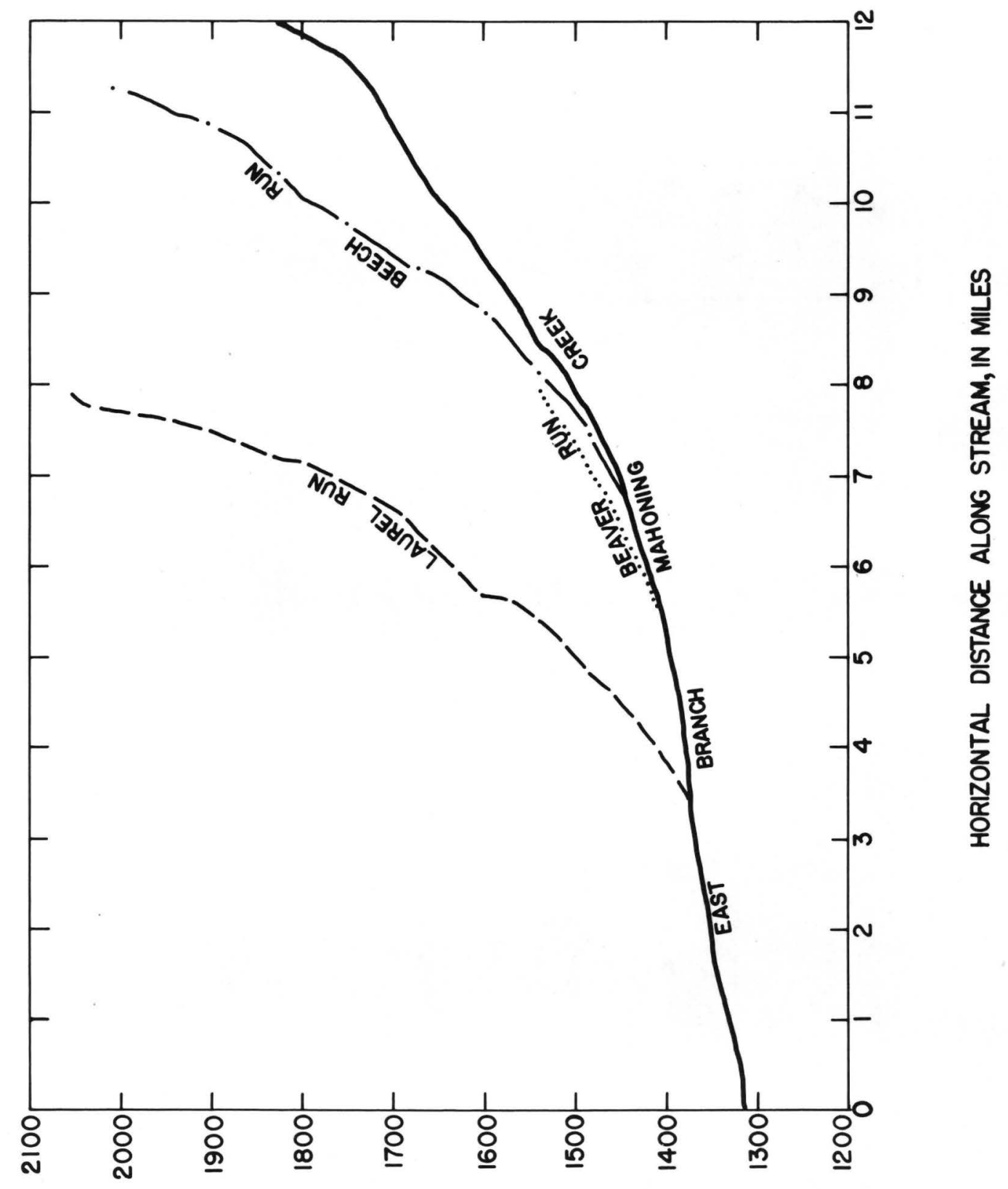

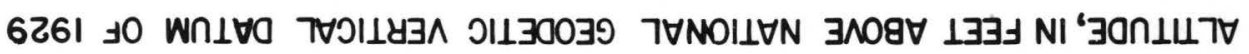

Figure 2.--Longitudinal profiles of streams in the East Branch Mahoning Creek basin. 
Coal deposits constitute the greatest mineral resource in the basin. All important seams are Pennsylvanian and occur in the Allegheny Group. The Upper and Lower Freeport coal seams, which contain the largest reserves in the basin, have an average thickness of 40 inches. Deep and shallow gas fields also occur throughout the basin.

\section{$\underline{\text { Soils }}$}

Major soils in the East Branch Mahoning Creek basin are of the GilpinErnest-Wharton Association (U.S. Department of Agriculture, 1964). This group is formed in materials weathered from noncarbonate sedimentary rocks, and when thoroughly wetted has slow infiltration rates that can result in high runoff. This group consists chiefly of soils with a layer that impedes downward movement of water or soils with moderately fine to fine texture. They also have a slow rate of water transmission.

Land Use

During the investigation, 60 percent of the basin was forested, 35 percent general cropland, and 2 percent towns and roads. The remaining 3 percent of the basin was reclaimed strip mines.

There are a number of man-induced sources of sediment to streams in the basin. Logging operations, unpaved haul roads, eroding reclaimed areas, farming, and surface mining contribute to the suspended sediment transported from the basin.

About 40 mining permits have been issued in the basin, 22 of which have begun active mining operations. At this time, 1,854 acres of land are disturbed. This number fluctuates as mining progresses and may reach 2,500 acres at times.

\section{Mining Practices}

Surface mining involves the removal of vegetation, top soil, and overburden (consolidated or unconsolidated material overlying a deposit of coal) above a seam of coal. There are two general methods of surface mining in use today, contour and block-cut mining. In contour mining, the first cut is made down slope and excavation proceeds around a hillside following the contour of the land. Additional cuts or excavations are made into the hillside above the first cut and the overburden is deposited down slope. The overburden forms a high ridge that is susceptible to erosion and landslides (fig. 3). Reclamation can begin only when the mining operation is completed.

In block-cut mining, the excavation is made perpendicular to contour lines. Overburden from a new cut is used to fill the pit from the previous cuts. Reclamation is integrated into the mining schedule and less overburden is exposed. In this type of mining, erosion and landslides are reduced because overburden is handled only once. 


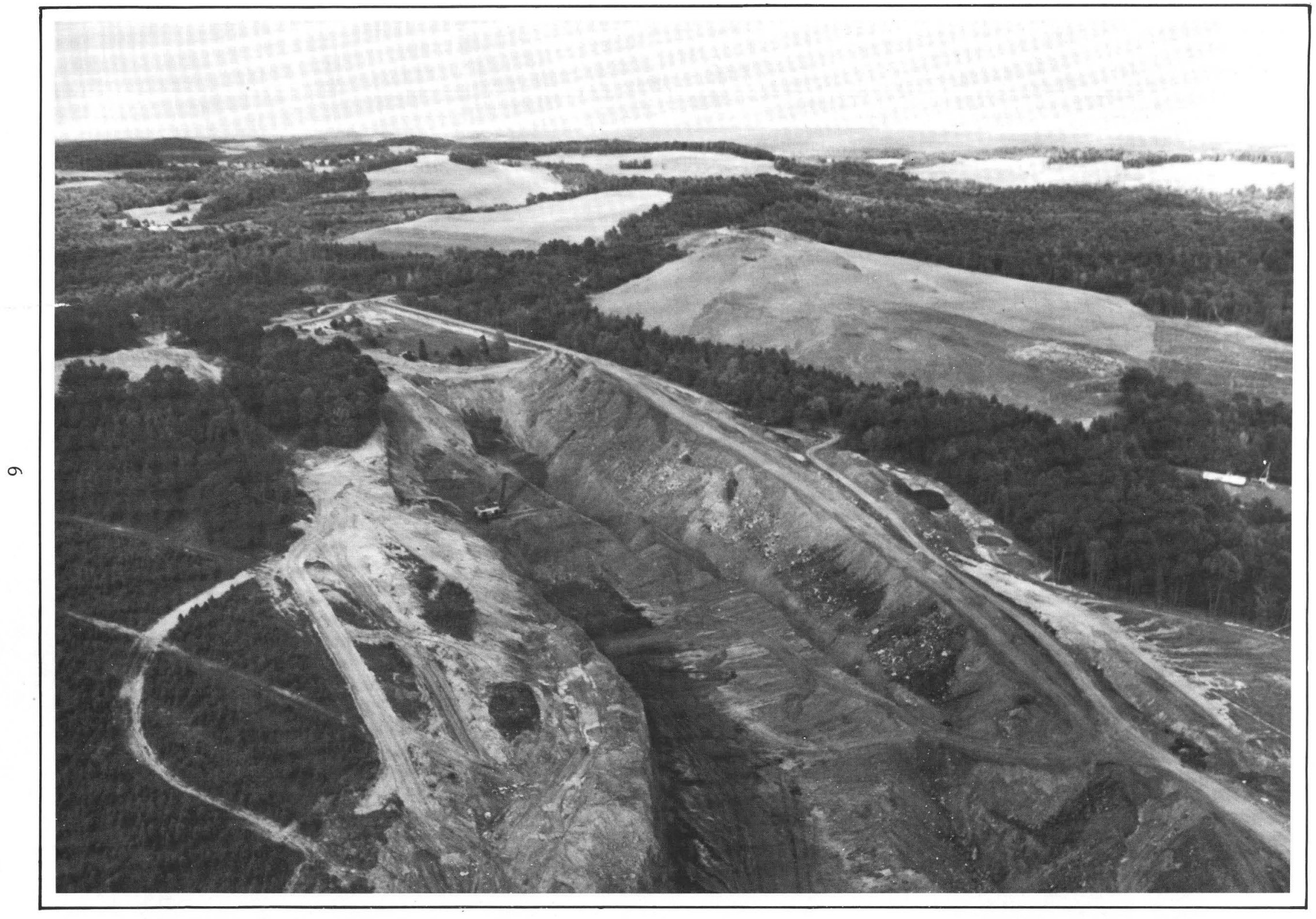

Figure 3.--Countour mining in the East Branch Mahoning Creek basin. 
The Department of Environmental Resources requires sediment controls on al1 active mining operations in the basin (oral communication, BMR, 1979). Some of the steps that can be implemented to reduce suspended-sediment discharge from mining areas are diversion and collection ditches and sedimentation ponds. Diversion ditches are constructed to transport surface runoff to a sedimentation pond or around a disturbed area. The ponds provide detention time for sediment particles to settle out. Additional procedures are rip-rap (various types), lining trenches, and mulching and planting immediately after topsoil is spread. The procedures for most mining operations differ because of the topography, equipment capability, and mining foreman experience.

\section{DATA COLLECTION AND ANALYSIS}

One precipitation station and two stream gaging stations were installed in 1979; a second precipitation station was installed in March 1980 (fig. 1). The precipitation stations are equipped with weighing-type graphic gages. The stream gaging stations are equipped with continuousgraphic stage recorders, and water discharge is determined using the standard procedures described by Carter and Davidian (1968).

Site 1, East Branch Mahoning Creek near Big Run, has been operated since June 1979. In addition to the stream gaging equipment at the site, there is an automatic pumping sampler and a recording turbidimeter. The PS-69 sampler collects samples twice daily during base flow and every hour during storms when streamflow and concentrations are high and change rapidly.

During December 1979, site 2, Beaver Run near Troutville, began operation. A smaller automatic pumping sampler (PS-67) is located at this site to collect samples every 30 minutes during storms. Hand samples are collected about every 3 days during base-flow periods.

Sediment samples were analyzed in the Survey's laboratory in Harrisburg by methods described by Guy (1969). The turbidity and specific conductance of each sample was also determined. Daily mean discharges were computed for streamflow, and daily mean concentrations and discharges were computed for sediment by techniques described by Porterfield (1972).

\section{PRECIPITATION}

During the first year, precipitation in the basin at site 1 totaled 50.7 in. Average annual precipitation, as determined from 20 years of record at nearby DuBois, was 41.6 in. At site 1, the maximum month1y rainfall of 5.94 in. was measured in September 1979, and the minimum monthly rainfall of 1.53 in. in January 1980 . Precipitation data recorded at the two sites in the basin, and from the longer term station at DuBois operated by the National Weather Service, are listed in table 1. 
Table 1.--Monthly precipitation, in inches

\begin{tabular}{|c|c|c|c|}
\hline Month & $\begin{array}{l}\text { U.S. G } \\
\text { Survey } \\
\text { No. } 1\end{array}$ & $\begin{array}{l}\text { cal } \\
\text { gages } \\
\text { No. } 2 \\
\end{array}$ & $\begin{array}{c}\text { National Weather } \\
\text { Service station } \\
\text { DuBois }\end{array}$ \\
\hline June 1979 & 1.64 & & 2.21 \\
\hline July & 4.44 & & 5.73 \\
\hline August & 4.25 & & 3.02 \\
\hline September & 5.94 & & 4.11 \\
\hline October & 3.77 & & 3.45 \\
\hline November & 5.63 & & 3.44 \\
\hline December & 3.27 & & 2.32 \\
\hline January 1980 & 1.53 & & 1.27 \\
\hline February & 2.04 & & 2.08 \\
\hline March & 5.41 & 3.68 & 6.70 \\
\hline April & 4.05 & 4.01 & 3.92 \\
\hline May & 4.97 & 4.22 & 3.10 \\
\hline June & 3.73 & 3.24 & 4.43 \\
\hline Total & 50.7 & $15 \cdot 2^{a /}$ & 45.8 \\
\hline
\end{tabular}

a/partial year 
Runoff from the basin totaled 23.9 in. or about 47 percent of the total precipitation for the period. The remaining 53 percent recharged the ground-water reservoirs, or was evaporated or transpired. Table 2 1ists the monthly precipitation and runoff and the amounts contributed by base flow and direct runoff.

During the winter and spring, precipitation and snowmelt readily percolate through unsaturated soils resulting in higher ground-water levels and, therefore, increased base flow. Evapotranspiration is minimal. Table 2 indicates that total runoff was generally over 50 percent of precipitation during winter and spring. When evapotranspiration rates are high, during summer and fall, a smaller amount of precipitation reaches the water table. Because recharge to ground-water reservoirs decreases, base flow decreases. Total runoff during the summer and fall was generally less than 30 percent of precipitation.

During the first year of data collection, the minimum daily flow at site 1 was $7.7 \mathrm{ft}^{3} / \mathrm{s}$ during July. Maximum instantaneous discharge, $645 \mathrm{ft}^{3} / \mathrm{s}$, occurred on November 26,1979 , when $2.20 \mathrm{in}$. of rain fell, $0.90 \mathrm{in.}$ of it in a 30-minute period. This was preceded by $0.82 \mathrm{in}$. of precipitation in the two days prior to November 26 .

The minimum daily flow observed at site 2, Beaver Run near Troutville, was $0.04 \mathrm{ft}^{3} / \mathrm{s}$ and occurred for two days in June 1980 . Maximum instantaneous discharge, $100 \mathrm{ft}^{3} / \mathrm{s}$, occurred on March 8, 1980 .

\section{TURBIDITY}

Turbidity is related to the amount of suspended material in water. In general, it reflects the size, shape, refractive index, and number of particles in suspension, and may be defined less precisely as an unclear condition or cloudiness of water.

Turbidity was measured on all sediment samples in the laboratory. It was also monitored continuously at site 1 with a surface-scatter turbidimeter. The field turbidity record was used as an aid in defining the continuous graph of suspended-sediment concentration.

The relation of turbidity to suspended-sediment concentration at both sites is shown in figures 4 and 5. The data, plotted from laboratory measurements of individual samples through June 1980, show a good degree of correlation.

In the absence of a sediment-measurement program in this basin, turbidity data could be used to obtain an approximation of suspended-sediment discharge. However, the relations may be unique and should not be used for other basins without first establishing a correlation. 
Table 2.--Precipitation and runoff, June 1979 to June 1980

\begin{tabular}{|c|c|c|c|c|c|}
\hline Month & $\begin{array}{l}\text { Precipitation } \\
\text { (inches) }\end{array}$ & (inches) & $\begin{array}{l}\text { runoff } \\
\text { (percent } \\
\text { of precipi- } \\
\text { tation) }\end{array}$ & $\begin{array}{l}\text { Direct } \\
\text { runoff } \\
\text { (inches) }\end{array}$ & $\begin{array}{l}\text { Base flow } \\
\text { (inches) }\end{array}$ \\
\hline June & 1.64 & 0.20 & 12 & 0.02 & 0.18 \\
\hline July & 4.44 & .51 & 11 & .18 & .33 \\
\hline August & 4.25 & .59 & 14 & .23 & .36 \\
\hline September & 5.94 & 1.3 & 22 & .89 & .41 \\
\hline October & 3.77 & 2.3 & 61 & 1.66 & .64 \\
\hline November & 5.63 & 2.2 & 40 & 1.26 & .94 \\
\hline December & 3.27 & 2.0 & 61 & .80 & 1.2 \\
\hline January & 1.53 & 1.4 & 92 & .57 & .83 \\
\hline February & 2.04 & 1.0 & 49 & .43 & .57 \\
\hline March & 5.41 & 4.6 & 85 & 2.6 & 2.0 \\
\hline April & 4.05 & 4.1 & 101 & 1.9 & 2.2 \\
\hline May & 4.97 & 2.6 & 52 & 1.6 & 1.0 \\
\hline June & 3.73 & 1.1 & 30 & .58 & .52 \\
\hline Total & 50.7 & 23.9 & & 12.7 & 11.2 \\
\hline
\end{tabular}




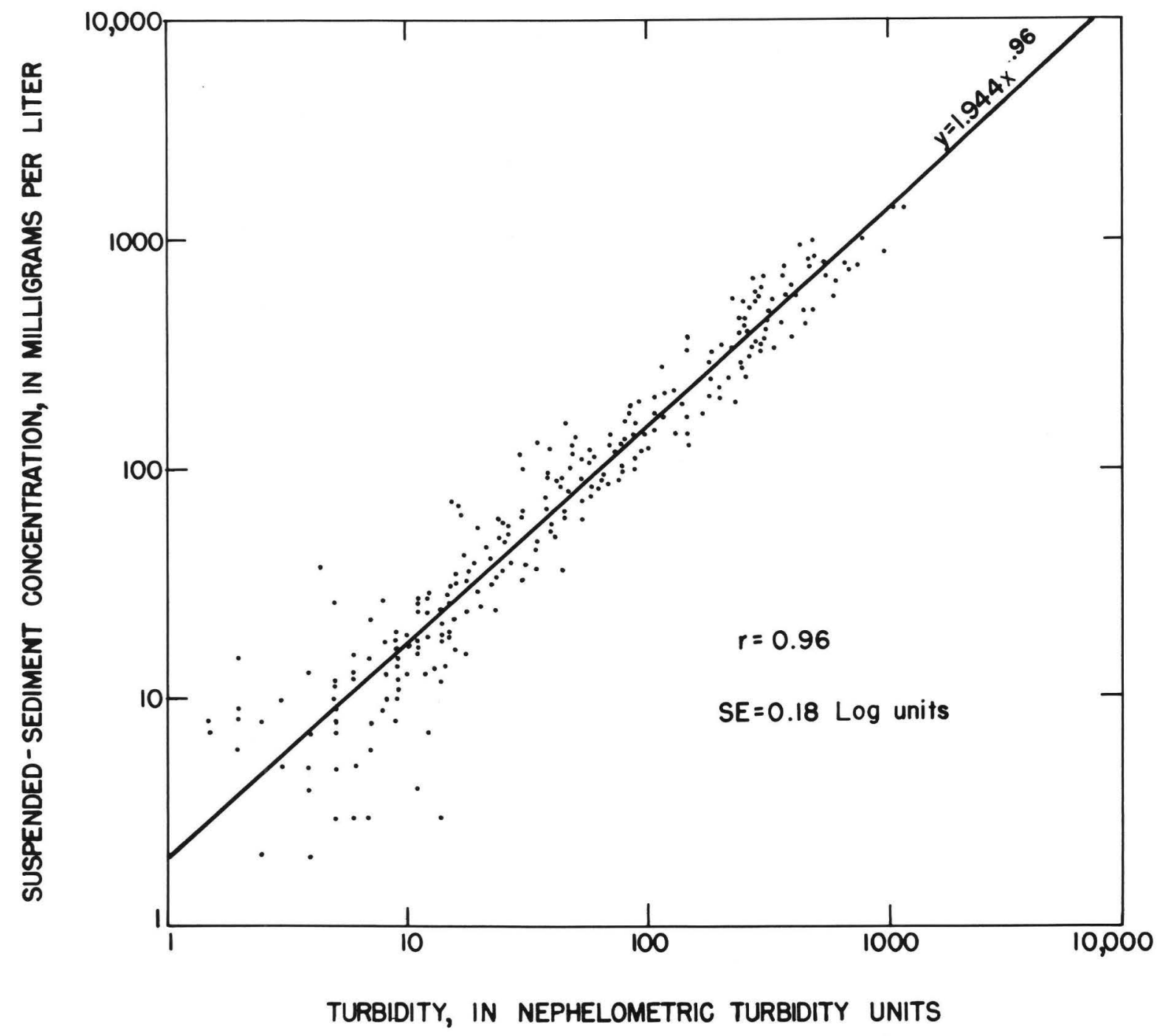

Figure 4.--Plot of turbidity and suspended-sediment concentrations at site 1, East Branch Mahoning Creek near Big Run. 


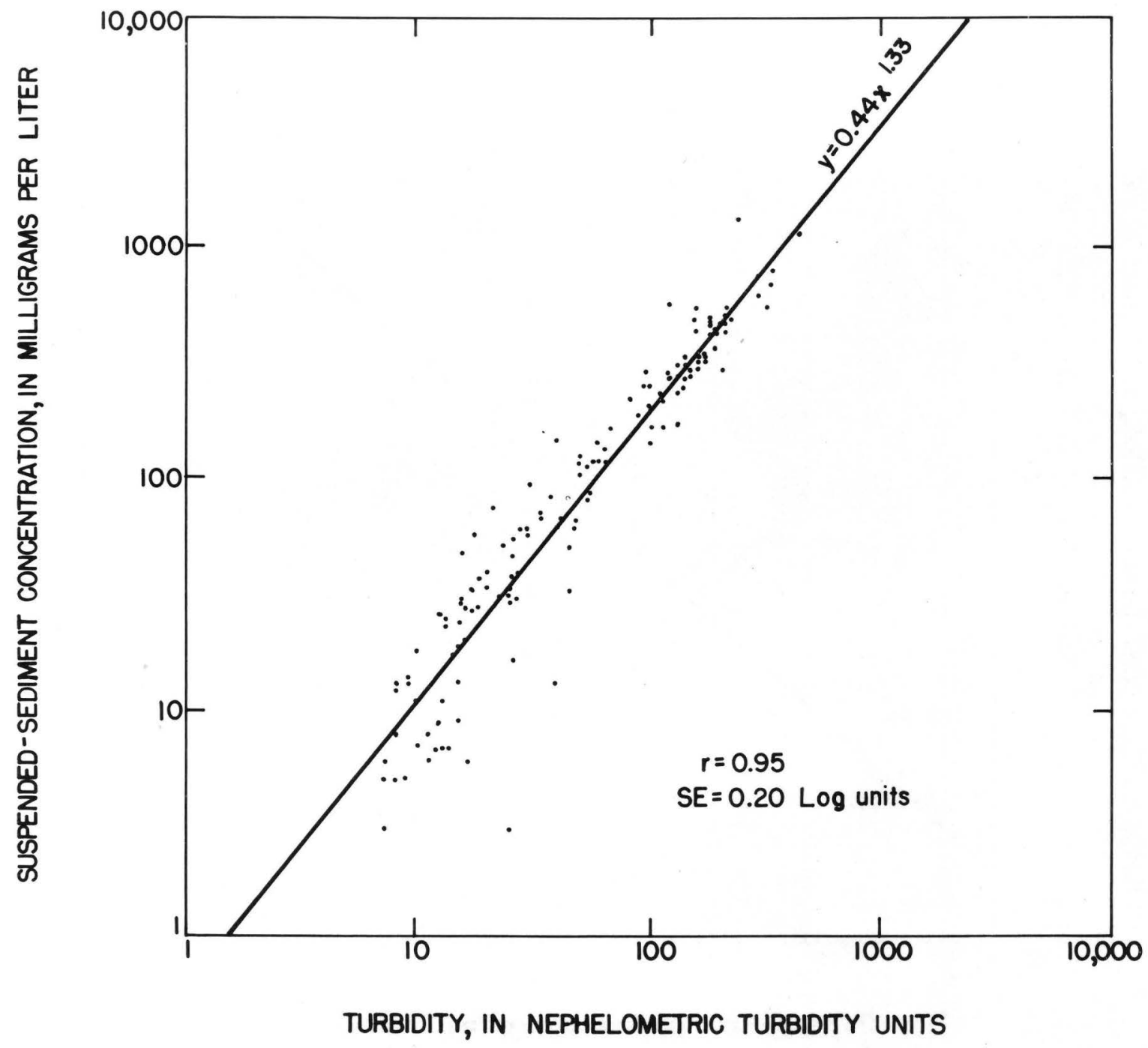

Figure 5.--Plot of turbidity and suspended-sediment concentrations at site 2, Beaver Run near Troutville. 
The response of streamflow, suspended sediment, specific conductance, and turbidity at both sites in the basin during a May 1980 storm is shown in figures 6 and 7. The storm on this date is typical of late spring and summer storms at both sites. Figure 6 shows plot of time versus the measured parameters at Beaver Run. Flow increased steadily from 0300 to 1000 on May 12 when it rose sharply until it peaked at 1230. Peak flow was $68 \mathrm{ft}^{3} / \mathrm{s}$. The rise in streamflow was accompanied by a sharp rise in suspended sediment and turbidity and a drop in specific conductance. The peak suspended-sediment concentration, $1,360 \mathrm{mg} / \mathrm{L}$, occurs simultaneously with the peak water discharge. A small preliminary peak occurs, probably a result of an initial flush of fine sediments in the stream channels.

A smaller storm occurred 1-1/2 days after the first storm. After the storm, the variables gradually returned to normal.

Figure 7 shows plot of time and associated parameters for East Branch Mahoning Creek for the same storm. The hydrograph peaks show that higher discharges occur for longer periods of time. Site 1 peaked at 1345 on May 12 at a discharge of $475 \mathrm{ft}^{3} / \mathrm{s}$. The peak suspended-sediment concentration, $864 \mathrm{mg} / \mathrm{L}$, preceded the peak flow. The suspended-sediment concentration exceeded $200 \mathrm{mg} / \mathrm{L}$ for a period of about 9-1/2 hours.

The specific conductance of the stream fell sharply at the beginning of the storm and was very slow in returning to base-flow levels. A second storm occurred about 1-1/2 days after the initial rise at site 1 .

The 3-day suspended-sediment load at Beaver Run was 42 tons; 30 tons passed the gage the first day. At site 1, the storm load totaled 380 tons; storm load for the first day was 258 tons.

\section{SEDIMENT CONCENTRATIONS AND DISCHARGES}

During the first year of data collection, 3,570 tons of sediment was transported from the East Branch Mahoning Creek basin. This was an average yield of 121 tons per square mile per year [(tons/mi $\left.\left.{ }^{2}\right) / y r\right]$. Month1y sediment discharges averaged 298 tons and ranged from 32 tons in July to 1,250 tons in March. The highest daily mean suspended-sediment concentration was $712 \mathrm{mg} / \mathrm{L}$ on June 8, 1980. On that date, 267 tons of sediment was discharged from the basin. The relation between suspended-sediment discharge and streamflow is shown in figure 8.

From December 1979 to June 1980, Beaver Run near Troutville discharged 328 tons of suspended sediment. This was an average yield of

148 (tons $/ \mathrm{mi}^{2}$ )/yr. The total sediment load transported from the entire basin for this period was 2,620 tons. The Beaver Run basin, which is less than one tenth of the entire basin, contributed 12 percent of the sediment load. The daily mean streamflow and daily mean concentrations and discharges of suspended sediment at both sites are listed in table 3 . 


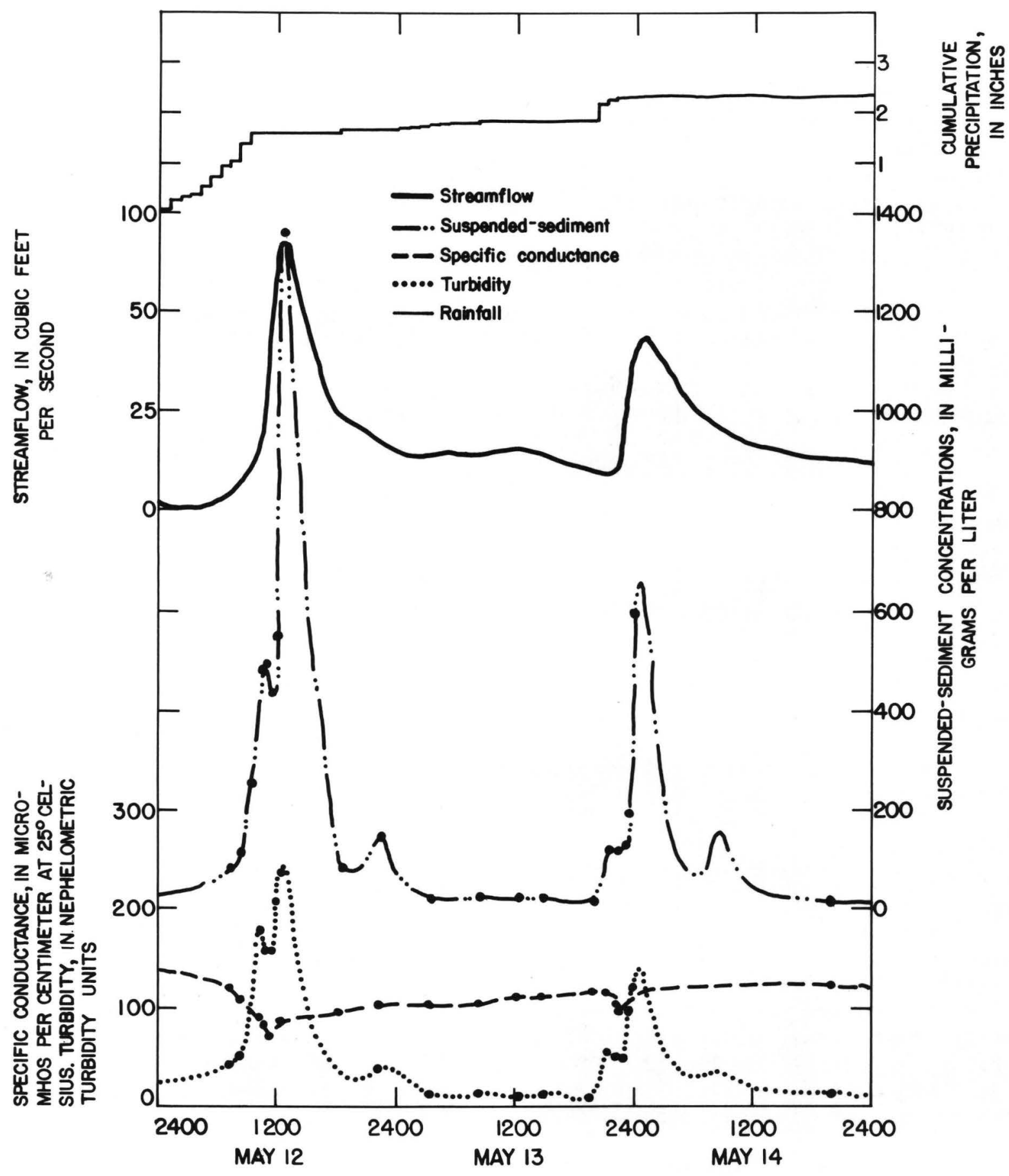

Figure 6.--Variations of constituents at site 2, Beaver Run near Troutville during the May 12-14 storm. 


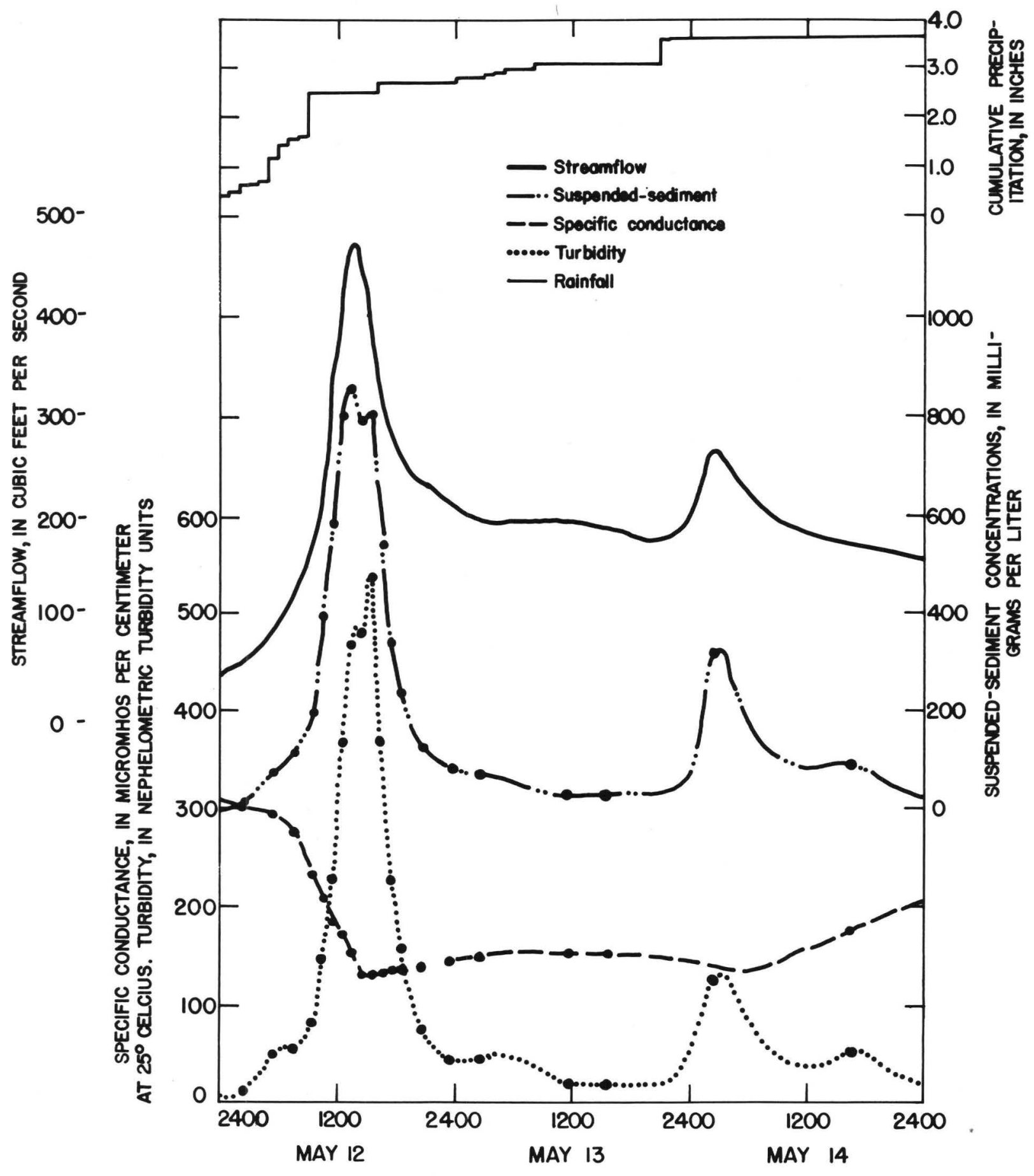

Figure 7.--Variations of constituents at site 1, East Branch Mahoning Creek near Big Run during the May 12-14 storm. 


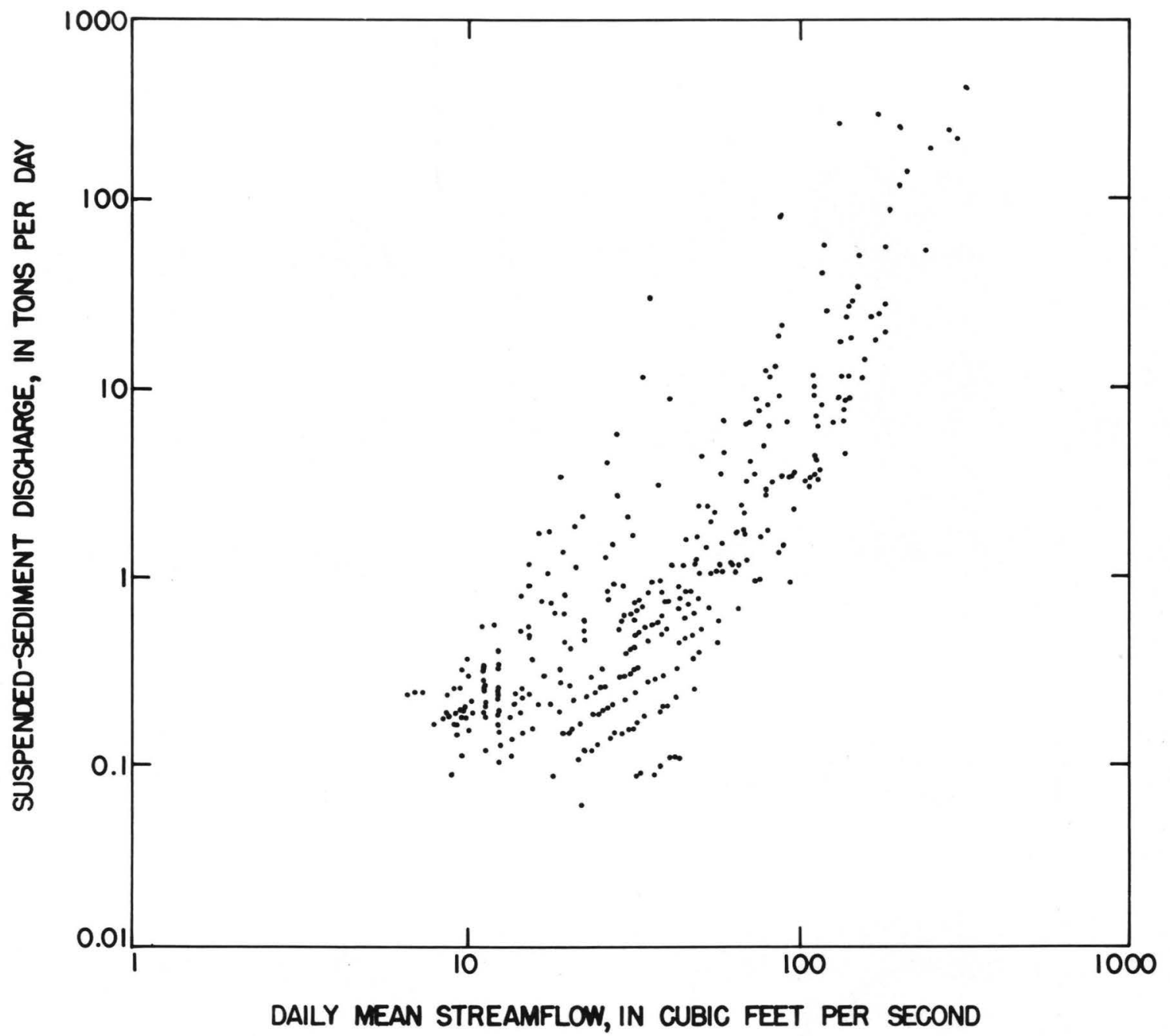

Figure 8.--Relation between suspended-sediment discharge and streamflow, East Branch Mahoning Creek near Big Run. 
Table 3.--Daily mean water-weighted concentrations and discharges

03033222 Beaver Run near Troutvil1e, Pa.

Sediment discharge, suspended (tons/day), water year October 1979 to September 1980

\begin{tabular}{|c|c|c|c|c|c|c|c|c|c|}
\hline Day & $\begin{array}{c}\text { Mean } \\
\text { discharge } \\
\left(\mathrm{ft}^{3} / \mathrm{s}\right)\end{array}$ & $\begin{array}{l}\text { Mean } \\
\text { concen- } \\
\text { tration } \\
(\mathrm{mg} / \mathrm{L}) \\
\end{array}$ & $\begin{array}{l}\text { Sediment } \\
\text { discharge } \\
\text { (tons/day) }\end{array}$ & $\begin{array}{c}\text { Mean } \\
\text { discharge } \\
\left(\mathrm{ft}^{3} / \mathrm{s}\right)\end{array}$ & $\begin{array}{l}\text { Mean } \\
\text { concen- } \\
\text { tration } \\
(\mathrm{mg} / \mathrm{L}) \\
\end{array}$ & $\begin{array}{l}\text { Sediment } \\
\text { discharge } \\
\text { (tons/day) }\end{array}$ & $\begin{array}{c}\text { Mean } \\
\text { discharge } \\
\left(\mathrm{ft}^{3} / \mathrm{s}\right)\end{array}$ & $\begin{array}{l}\text { Mean } \\
\text { concen- } \\
\text { tration } \\
(\mathrm{mg} / \mathrm{L})\end{array}$ & $\begin{array}{l}\text { Sediment } \\
\text { discharge } \\
\text { (tons/day) }\end{array}$ \\
\hline & & October & & & November & & & December & \\
\hline 1 & & & & & & & -- & -- & -- \\
\hline 2 & & & & & & & -- & --- & --- \\
\hline 3 & & & & & & & -- & -- & -- \\
\hline 4 & & & & & & & -- & --- & -- \\
\hline 5 & & & & & & & --- & -- & --- \\
\hline 6 & & & & & & & -- & --- & -- \\
\hline 7 & & & & & & & -- & -- & -- \\
\hline 8 & & & & & & & -- & --- & -- \\
\hline 9 & & & & & & & -- & -- & --- \\
\hline 10 & & & & & & & -- & --- & --- \\
\hline 11 & & & & & & & -- & --- & -- \\
\hline 12 & & & & & & & -- & -- & -- \\
\hline 13 & & & & & & & -- & --- & -- \\
\hline 14 & & & & & & & -- & --- & --- \\
\hline 15 & & & & & & & --- & --- & --- \\
\hline 16 & & & & & & & -- & --- & --- \\
\hline 17 & & & & & & & --- & -- & -- \\
\hline 18 & & & & & & & .70 & -- & --- \\
\hline 19 & & & & & & & .70 & -- & -- \\
\hline 20 & & & & & & & .62 & -- & -- \\
\hline 21 & & & & & & & .55 & -- & -- \\
\hline 22 & & & & & & & .55 & --- & --- \\
\hline 23 & & & & & & & .62 & -- & -- \\
\hline 24 & & & & & & & 1.4 & --- & --- \\
\hline 25 & & & & & & & 14 & --- & -- \\
\hline 26 & & & & & & & 5.2 & -- & -- \\
\hline 27 & & & & & & & 3.0 & 5 & .04 \\
\hline 28 & & & & & & & 2.3 & 5 & .03 \\
\hline 29 & & & & & & & 1.8 & 5 & .02 \\
\hline 30 & & & & & & & 1.6 & 4 & .02 \\
\hline 31 & & & & & & & 1.4 & 4 & .02 \\
\hline Total & & & & & & & 34.44 & --- & 0.13 \\
\hline
\end{tabular}


Table 3.--Daily mean water-weighted concentrations and discharges--continued

03033222 Beaver Run near Troutville, Pa.--continued

Sediment discharge, suspended (tons/day), water year October 1979 to September 1980--continued

\begin{tabular}{|c|c|c|c|c|c|c|c|c|c|}
\hline Day & $\begin{array}{l}\text { Mean } \\
\text { discharge } \\
(\mathrm{ft} / \mathrm{s}) \\
\end{array}$ & $\begin{array}{l}\text { Mean } \\
\text { concen- } \\
\text { tration } \\
(\mathrm{mg} / \mathrm{L}) \\
\end{array}$ & $\begin{array}{l}\text { Sediment } \\
\text { discharge } \\
\text { (tons/day) }\end{array}$ & $\begin{array}{c}\text { Mean } \\
\text { discharge } \\
\left(\mathrm{ft}^{3} / \mathrm{s}\right)\end{array}$ & $\begin{array}{l}\text { Mean } \\
\text { concen- } \\
\text { tration } \\
(\mathrm{mg} / \mathrm{L}) \\
\end{array}$ & $\begin{array}{l}\text { Sediment } \\
\text { discharge } \\
\text { (tons/day) }\end{array}$ & $\begin{array}{c}\text { Mean } \\
\text { discharge } \\
\left(\mathrm{ft}^{3} / \mathrm{s}\right)\end{array}$ & $\begin{array}{l}\text { Mean } \\
\text { concen- } \\
\text { tration } \\
(\mathrm{mg} / \mathrm{L})\end{array}$ & $\begin{array}{l}\text { Sediment } \\
\text { discharge } \\
\text { (tons/day) }\end{array}$ \\
\hline & & January & & & February & & & March & \\
\hline 1 & 1.1 & 4 & 0.01 & 0.10 & 3 & 0.00 & 0.22 & 4 & 0.00 \\
\hline 2 & .98 & 3 & .00 & .10 & 3 & .00 & .17 & 4 & .00 \\
\hline 3 & .88 & 3 & .00 & .10 & 2 & .00 & .11 & 3 & .00 \\
\hline 4 & .70 & 3 & .00 & .10 & 2 & .00 & .08 & 6 & .00 \\
\hline 5 & .70 & 3 & .00 & .10 & 5 & .00 & 31 & 256 & 21 \\
\hline 6 & 3.2 & 24 & .21 & .09 & 4 & .00 & 4.1 & 105 & 1.2 \\
\hline 7 & .49 & 4 & .00 & .09 & 5 & .00 & 3.0 & 353 & 2.9 \\
\hline 8 & .38 & 3 & .00 & .09 & 6 & .00 & 53 & 689 & 99 \\
\hline 9 & .60 & 4 & .00 & .09 & 5 & .00 & 4.3 & 42 & .49 \\
\hline 10 & .81 & 9 & .02 & .09 & 5 & .00 & 3.3 & 8 & .07 \\
\hline 11 & 1.2 & 32 & .10 & .09 & 4 & .00 & 2.0 & 10 & .05 \\
\hline 12 & 3.5 & 58 & .55 & .09 & 4 & .00 & .88 & 8 & .02 \\
\hline 13 & .38 & 8 & .00 & .09 & 3 & .00 & .70 & 6 & .01 \\
\hline 14 & 2.0 & 40 & .22 & .09 & 3 & .00 & .70 & 6 & .01 \\
\hline 15 & 1.2 & 12 & .04 & .09 & 2 & .00 & .49 & 5 & .00 \\
\hline 16 & .62 & 10 & .02 & .08 & 3 & .00 & 2.5 & 133 & .90 \\
\hline 17 & .44 & 11 & .01 & .08 & 6 & .00 & 18 & 458 & 22 \\
\hline 18 & .28 & 10 & .00 & .08 & 5 & .00 & 20 & 149 & 8.0 \\
\hline 19 & .25 & 8 & .00 & .08 & 3 & .00 & 4.3 & 10 & .12 \\
\hline 20 & .24 & 7 & .00 & .08 & 3 & .00 & 3.3 & 6 & .05 \\
\hline 21 & .21 & 4 & .00 & 9.5 & 120 & 3.1 & 8.0 & 36 & .78 \\
\hline 22 & .19 & 4 & .00 & 35 & 129 & 12 & 4.6 & 9 & .11 \\
\hline 23 & .18 & 4 & .00 & 5.8 & 60 & .94 & 4.0 & 25 & .27 \\
\hline 24 & .17 & 3 & .00 & 2.1 & 24 & .14 & 4.4 & 13 & .15 \\
\hline 25 & .16 & 4 & .00 & 1.2 & 12 & .04 & 3.9 & 6 & .06 \\
\hline 26 & .15 & 3 & .00 & .70 & 7 & .01 & 2.3 & 5 & .03 \\
\hline 27 & .13 & 5 & .00 & .49 & 6 & .00 & 2.0 & 4 & .02 \\
\hline 28 & .13 & 4 & .00 & .44 & 5 & .00 & 1.8 & 7 & .03 \\
\hline 29 & .12 & 3 & .00 & .38 & 5 & .00 & 9.9 & 100 & 2.7 \\
\hline 30 & .12 & 3 & .00 & -- & -- & -- & 5.0 & 44 & .59 \\
\hline 31 & .11 & 3 & .00 & -- & --- & -- & 31 & 220 & 18 \\
\hline Total & 21.62 & --- & 1.18 & 57.41 & --- & 16.23 & 229.05 & --- & 178.56 \\
\hline
\end{tabular}


Table 3.--Daily mean water-weighted concentrations and discharge--continued

03033222 Beaver Run near Troutville, Pa.--continued

Sediment discharge, suspended (tons/day), water year October 1979 to September 1980--continued

\begin{tabular}{|c|c|c|c|c|c|c|c|c|c|}
\hline Day & $\begin{array}{l}\text { Mean } \\
\text { discharge } \\
\left(\mathrm{ft} \mathrm{t}^{3} / \mathrm{s}\right)\end{array}$ & $\begin{array}{l}\text { Mean } \\
\text { concen- } \\
\text { tration } \\
(\mathrm{mg} / \mathrm{L}) \\
\end{array}$ & $\begin{array}{l}\text { Sediment } \\
\text { discharge } \\
\text { (tons/day) }\end{array}$ & $\begin{array}{c}\text { Mean } \\
\text { discharge } \\
\left(f t^{3} / \mathrm{s}\right)\end{array}$ & $\begin{array}{l}\text { Mean } \\
\text { concen- } \\
\text { tration } \\
(\mathrm{mg} / \mathrm{L}) \\
\end{array}$ & $\begin{array}{l}\text { Sediment } \\
\text { discharge } \\
\text { (tons/day) }\end{array}$ & $\begin{array}{c}\text { Mean } \\
\text { discharge } \\
\left(\mathrm{ft}^{3} / \mathrm{s}\right) \\
\end{array}$ & $\begin{array}{l}\text { Mean } \\
\text { concen- } \\
\text { tration } \\
(\mathrm{mg} / \mathrm{L})\end{array}$ & $\begin{array}{l}\text { Sediment } \\
\text { discharge } \\
\text { (tons/day) }\end{array}$ \\
\hline & & Apri1 & & & May & & & June & \\
\hline 1 & 22 & 45 & 2.7 & 1.6 & 6 & 0.03 & 0.31 & 8 & 0.00 \\
\hline 2 & 12 & 8 & .26 & 1.4 & 5 & .02 & .36 & 7 & .00 \\
\hline 3 & 7.0 & 7 & .13 & 1.4 & 7 & .03 & .31 & 8 & .00 \\
\hline 4 & 7.0 & 12 & .23 & 1.1 & 6 & .02 & .19 & 9 & .00 \\
\hline 5 & 5.2 & 5 & .07 & .88 & 6 & .01 & .10 & 8 & .00 \\
\hline 6 & 3.3 & 4 & .04 & .78 & 5 & .01 & .10 & 7 & .00 \\
\hline 7 & 2.3 & 5 & .03 & .70 & 6 & .01 & .15 & 179 & .07 \\
\hline 8 & 5.0 & 381 & 5.1 & .55 & 5 & .00 & 12 & 248 & 8.0 \\
\hline 9 & 40 & 633 & 68 & .44 & 5 & .00 & 3.9 & 27 & .28 \\
\hline 10 & 14 & 25 & .95 & .38 & 4 & .00 & 3.8 & 12 & .12 \\
\hline 11 & 8.6 & 6 & .14 & .48 & 18 & .02 & 2.1 & 6 & .03 \\
\hline 12 & 6.5 & 14 & .25 & 20 & 557 & 30 & 1.4 & 6 & .02 \\
\hline 13 & 5.7 & 13 & .20 & 13 & 46 & 1.6 & 1.0 & 5 & .01 \\
\hline 14 & 10 & 35 & .95 & 20 & 186 & 10 & .80 & 5 & .01 \\
\hline 15 & 11 & 18 & .53 & 7.5 & 11 & .22 & .76 & 6 & .01 \\
\hline 16 & 6.4 & 13 & .22 & 3.9 & 7 & .07 & .84 & 7 & .02 \\
\hline 17 & 4.4 & 13 & .15 & 2.5 & 6 & .04 & .41 & 5 & .00 \\
\hline 18 & 3.0 & 10 & .08 & 3.0 & 12 & .10 & .36 & 5 & .00 \\
\hline 19 & 2.1 & 10 & .06 & 2.1 & 6 & .03 & .27 & 5 & .00 \\
\hline 20 & 1.6 & 11 & .05 & 1.6 & 5 & .02 & .36 & 8 & .00 \\
\hline 21 & 1.5 & 13 & .05 & 1.5 & 5 & .02 & .27 & 6 & .00 \\
\hline 22 & 1.5 & 12 & .05 & 1.4 & 5 & .02 & .19 & 5 & .00 \\
\hline 23 & 1.2 & 9 & .03 & .98 & 5 & .01 & .16 & 5 & .00 \\
\hline 24 & 1.1 & 8 & .02 & .98 & 5 & .01 & .10 & 14 & .00 \\
\hline 25 & .88 & 7 & .02 & .70 & 6 & .01 & .08 & 6 & .00 \\
\hline 26 & .78 & 6 & .01 & .49 & 6 & .00 & .06 & 5 & .00 \\
\hline 27 & .91 & 6 & .01 & .38 & 7 & .00 & .04 & 8 & .00 \\
\hline 28 & 1.3 & 17 & .06 & .31 & 8 & .00 & .04 & 12 & .00 \\
\hline 29 & 3.2 & 31 & .27 & .31 & 8 & .00 & .08 & 9 & .00 \\
\hline 30 & 1.8 & 8 & .04 & .36 & 9 & .00 & .08 & 10 & .00 \\
\hline 31 & -- & -- & -- & .47 & 9 & .01 & -- & --- & -- \\
\hline Total & 191.27 & --- & 80.70 & 91.19 & --- & 42.31 & 30.62 & --- & 8.57 \\
\hline
\end{tabular}


Table 3.--Daily mean water-weighted concentrations and discharges--continued

03033225 East Branch Mahoning Creek near Big Run, Pa.

Sediment discharge, suspended (tons/day), water year October 1978 to September 1979

\begin{tabular}{|c|c|c|c|c|c|c|c|c|c|}
\hline Day & $\begin{array}{l}\text { Mean } \\
\text { discharge } \\
\left(\mathrm{ft}^{3} / \mathrm{s}\right)\end{array}$ & $\begin{array}{l}\text { Mean } \\
\text { concen- } \\
\text { tration } \\
(\mathrm{mg} / \mathrm{L})\end{array}$ & $\begin{array}{l}\text { Sediment } \\
\text { discharge } \\
\text { (tons/day) }\end{array}$ & $\begin{array}{c}\text { Mean } \\
\text { discharge } \\
\left(\mathrm{ft}^{3} / \mathrm{s}\right)\end{array}$ & $\begin{array}{l}\text { Mean } \\
\text { concen- } \\
\text { tration } \\
(\mathrm{mg} / \mathrm{L})\end{array}$ & $\begin{array}{l}\text { Sediment } \\
\text { discharge } \\
\text { (tons/day) }\end{array}$ & $\begin{array}{c}\text { Mean } \\
\text { discharge } \\
\left(\mathrm{ft}^{3} / \mathrm{s}\right)\end{array}$ & $\begin{array}{l}\text { Mean } \\
\text { concen- } \\
\text { tration } \\
(\mathrm{mg} / \mathrm{L})\end{array}$ & $\begin{array}{l}\text { Sediment } \\
\text { discharge } \\
\text { (tons/day) }\end{array}$ \\
\hline
\end{tabular}

Apri1

May

June

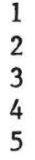

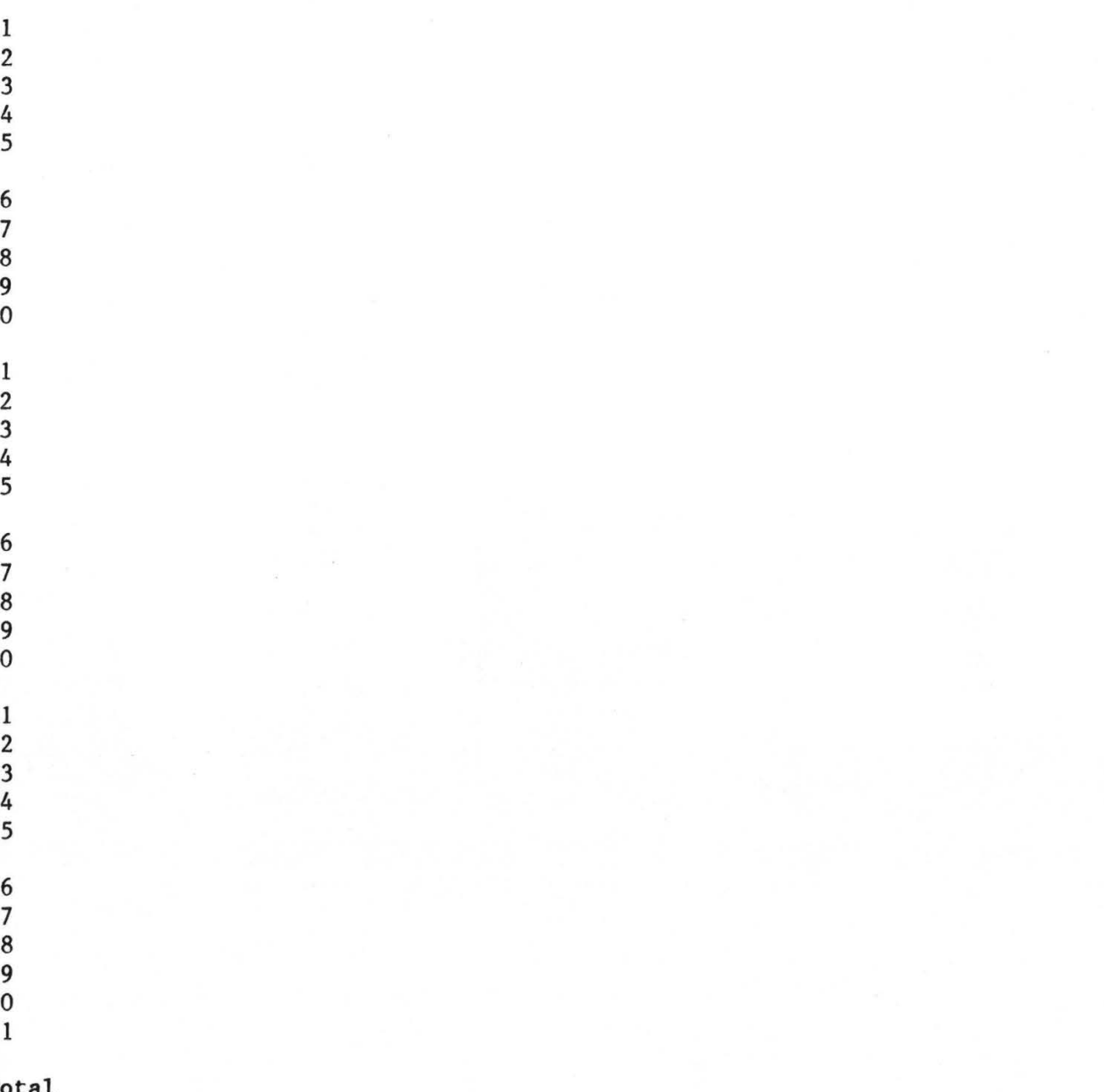

\begin{tabular}{|c|c|c|}
\hline-- & -- & -- \\
\hline-- & -- & -- \\
\hline-- & -- & -- \\
\hline--- & -- & -- \\
\hline-- & -- & -- \\
\hline-- & -- & -- \\
\hline-- & -- & --- \\
\hline --- & --- & --- \\
\hline-- & -- & --- \\
\hline-- & -- & -- \\
\hline-- & --- & -- \\
\hline-- & -- & -- \\
\hline- & -- & -- \\
\hline & -- & -- \\
\hline 12 & 5 & .17 \\
\hline 12 & 5 & .16 \\
\hline 11 & 6 & .18 \\
\hline 11 & 8 & .23 \\
\hline 11 & 8 & .23 \\
\hline 10 & 7 & .19 \\
\hline 9.7 & 7 & .18 \\
\hline 10 & 9 & .25 \\
\hline 9.7 & 8 & .21 \\
\hline 9.2 & 8 & .20 \\
\hline 8.8 & 8 & .19 \\
\hline 8.6 & 8 & .19 \\
\hline 8.1 & 8 & .18 \\
\hline 8.4 & 9 & .20 \\
\hline 8.6 & 8 & .19 \\
\hline 11 & 10 & .30 \\
\hline & -- & -- \\
\hline 59 & -- & 3.25 \\
\hline
\end{tabular}


Table 3.--Daily mean water-weighted concentrations and discharges--continued 03033225 East Branch Mahoning Creek near Big Run, Pa.--continued

Sediment discharge, suspended (tons/day), water year October 1978 to September 1979--continued

\begin{tabular}{|c|c|c|c|c|c|c|c|c|c|}
\hline Day & $\begin{array}{c}\text { Mean } \\
\text { discharge } \\
\left(\mathrm{ft} \mathrm{t}^{3} / \mathrm{s}\right)\end{array}$ & $\begin{array}{l}\text { Mean } \\
\text { concen- } \\
\text { tration } \\
(\mathrm{mg} / \mathrm{L})\end{array}$ & $\begin{array}{l}\text { Sediment } \\
\text { discharge } \\
\text { (tons/day) }\end{array}$ & $\begin{array}{c}\text { Mean } \\
\text { discharge } \\
\left(\mathrm{ft}^{3} / \mathrm{s}\right)\end{array}$ & $\begin{array}{l}\text { Mean } \\
\text { concen- } \\
\text { tration } \\
(\mathrm{mg} / \mathrm{L}) \\
\end{array}$ & $\begin{array}{l}\text { Sediment } \\
\text { discharge } \\
\text { (tons/day) }\end{array}$ & $\begin{array}{c}\text { Mean } \\
\text { discharge } \\
\left(\mathrm{ft}^{3} / \mathrm{s}\right) \\
\end{array}$ & $\begin{array}{l}\text { Mean } \\
\text { concen- } \\
\text { tration } \\
(\mathrm{mg} / \mathrm{L})\end{array}$ & $\begin{array}{l}\text { Sediment } \\
\text { discharge } \\
\text { (tons/day) }\end{array}$ \\
\hline & & July & & & August & & & September & \\
\hline 1 & 15 & 30 & 1.2 & 35 & 334 & 32 & 11 & 8 & 0.23 \\
\hline 2 & 13 & 7 & .25 & 19 & 72 & 3.6 & 10 & 9 & .25 \\
\hline 3 & 11 & 12 & .34 & 16 & 42 & 1.8 & 11 & 9 & .26 \\
\hline 4 & 12 & 11 & .36 & 12 & 18 & .58 & 10 & 8 & .22 \\
\hline 5 & 11 & 12 & .36 & 10 & 14 & .39 & 9.5 & 7 & .18 \\
\hline 6 & 9.5 & 8 & .20 & 9.9 & 12 & .32 & 187 & 600 & 303 \\
\hline 7 & 8.6 & 8 & .19 & 9.2 & 11 & .27 & 85 & 53 & 12 \\
\hline 8 & 8.1 & 8 & .18 & 8.8 & 11 & .26 & 49 & 19 & 2.5 \\
\hline 9 & 7.7 & 8 & .17 & 8.4 & 11 & .25 & 36 & 6 & .59 \\
\hline 10 & 34 & 130 & 12 & 11 & 19 & .56 & 29 & 5 & .39 \\
\hline 11 & 17 & 39 & 1.8 & 26 & 59 & 4.1 & 24 & 4 & .26 \\
\hline 12 & 12 & 13 & .42 & 28 & 37 & 2.8 & 20 & 4 & .22 \\
\hline 13 & 15 & 23 & .92 & 19 & 16 & .80 & 18 & 7 & .33 \\
\hline 14 & 28 & 82 & 6.2 & 14 & 7 & .26 & 22 & 9 & .53 \\
\hline 15 & 21 & 33 & 1.9 & 12 & 7 & .23 & 22 & 8 & .47 \\
\hline 16 & 14 & 21 & .79 & 12 & 8 & .25 & 16 & 7 & .31 \\
\hline 17 & 12 & 11 & .34 & 10 & 8 & .22 & 14 & 6 & .23 \\
\hline 18 & 11 & 8 & .23 & 11 & 7 & .20 & 12 & 6 & .20 \\
\hline 19 & 10 & 7 & .19 & 18 & 14 & .66 & 14 & 7 & .27 \\
\hline 20 & 9.2 & 5 & .12 & 11 & 9 & .26 & 12 & 5 & .16 \\
\hline 21 & 9.0 & 5 & .12 & 10 & 6 & .16 & 17 & 17 & .78 \\
\hline 22 & 8.6 & 4 & .09 & 9.0 & 6 & .15 & 31 & 21 & 1.7 \\
\hline 23 & 9.0 & 7 & .17 & 8.8 & 7 & .17 & 17 & 5 & .22 \\
\hline 24 & 11 & 7 & .21 & 9.7 & 7 & .18 & 14 & 4 & .15 \\
\hline 25 & 12 & 4 & .13 & 10 & 6 & .16 & 12 & 3 & .10 \\
\hline 26 & 14 & 14 & .53 & 11 & 9 & .27 & 12 & 4 & .13 \\
\hline 27 & 11 & 10 & .28 & 41 & 87 & 9.6 & 11 & 4 & .12 \\
\hline 28 & 9.5 & 13 & .33 & 21 & 22 & 1.2 & 91 & 354 & 87 \\
\hline 29 & 17 & 25 & 1.1 & 19 & 13 & .65 & 157 & 87 & 37 \\
\hline 30 & 15 & 14 & .58 & 15 & 9 & .37 & 84 & 15 & 3.4 \\
\hline 31 & 11 & 10 & .28 & 12 & 8 & .27 & --- & --- & --- \\
\hline Tota1 & 406.2 & --- & 31.98 & 466.8 & -- & 62.99 & 1057.5 & --- & 453.20 \\
\hline
\end{tabular}


Table 3.--Daily mean water-weighted concentrations and discharges--continued

03033225 East Branch Mahoning Creek near Big Run, Pa.--continued

Sediment discharge, suspended (tons/day), water year October 1979 to September 1980

\begin{tabular}{|c|c|c|c|c|c|c|c|c|c|}
\hline Day & $\begin{array}{l}\text { Mean } \\
\text { discharge } \\
\left(\mathrm{ft} \mathrm{t}^{3} / \mathrm{s}\right)\end{array}$ & \begin{tabular}{l}
\multicolumn{1}{c}{ Mean } \\
concen- \\
tration \\
$(\mathrm{mg} / \mathrm{L})$ \\
\end{tabular} & $\begin{array}{l}\text { Sediment } \\
\text { discharge } \\
\text { (tons/day) }\end{array}$ & $\begin{array}{c}\text { Mean } \\
\text { discharge } \\
\left(\mathrm{ft} \mathrm{t}^{3} / \mathrm{s}\right)\end{array}$ & \begin{tabular}{l}
\multicolumn{1}{c}{ Mean } \\
concen- \\
tration \\
$(\mathrm{mg} / \mathrm{L})$
\end{tabular} & $\begin{array}{l}\text { Sediment } \\
\text { discharge } \\
\text { (tons/day) }\end{array}$ & $\begin{array}{c}\text { Mean } \\
\text { discharge } \\
\left(\mathrm{ft}^{3} / \mathrm{s}\right)\end{array}$ & \begin{tabular}{l}
\multicolumn{1}{c}{ Mean } \\
concen- \\
tration \\
$(\mathrm{mg} / \mathrm{L})$ \\
\end{tabular} & $\begin{array}{l}\text { Sediment } \\
\text { discharge } \\
\text { (tons/day) }\end{array}$ \\
\hline & & October & & & November & & & December & \\
\hline 1 & 61 & 7 & 1.2 & 20 & 5 & 0.27 & 65 & 6 & 1.1 \\
\hline 2 & 48 & 5 & .65 & 59 & 30 & 4.8 & 56 & 4 & .60 \\
\hline 3 & 90 & 40 & 9.7 & 53 & 8 & 1.1 & 46 & 3 & .37 \\
\hline 4 & 62 & 7 & 1.2 & 40 & 1 & .11 & 42 & 1 & .11 \\
\hline 5 & 160 & 123 & 53 & 36 & 1 & .10 & 40 & 1 & .11 \\
\hline 6 & 167 & 34 & 15 & 35 & 1 & .09 & 39 & 2 & .21 \\
\hline 7 & 143 & 12 & 4.6 & 36 & 2 & .19 & 43 & 7 & .81 \\
\hline 8 & 118 & 12 & 3.8 & 33 & 2 & .18 & 38 & 5 & .51 \\
\hline 9 & 116 & 11 & 3.4 & 32 & 1 & .09 & 31 & 9 & .75 \\
\hline 10 & 108 & 11 & 3.2 & 65 & 10 & 1.8 & 30 & 5 & .41 \\
\hline 11 & 90 & 6 & 1.5 & 49 & 6 & .79 & 29 & 4 & .31 \\
\hline 12 & 75 & 5 & 1.0 & 42 & 2 & .23 & 30 & 4 & .32 \\
\hline 13 & 71 & 7 & 1.3 & 42 & 1 & .11 & 53 & 14 & 2.0 \\
\hline 14 & 55 & 3 & .45 & 39 & 1 & .11 & 59 & 10 & 1.6 \\
\hline 15 & 46 & 4 & .50 & 38 & 2 & .21 & 47 & 2 & .25 \\
\hline 16 & 40 & 5 & .54 & 50 & 4 & .54 & 45 & 5 & .61 \\
\hline 17 & 38 & 3 & .31 & 42 & 3 & .34 & 42 & 6 & .68 \\
\hline 18 & 33 & 2 & .18 & 38 & 3 & .31 & 40 & 7 & .76 \\
\hline 19 & 30 & 2 & .16 & 34 & 3 & .28 & 38 & 10 & 1.0 \\
\hline 20 & 28 & 2 & .15 & 31 & 2 & .17 & 35 & 10 & .95 \\
\hline 21 & 26 & 2 & .14 & 29 & 2 & .16 & 32 & 9 & .78 \\
\hline 22 & 24 & 3 & .19 & 29 & 3 & .23 & 31 & 5 & .42 \\
\hline 23 & 25 & 5 & .34 & 29 & 3 & .23 & 31 & 7 & .59 \\
\hline 24 & 29 & 12 & .94 & 45 & 14 & 1.7 & 42 & 8 & .91 \\
\hline 25 & 24 & 3 & .19 & 49 & 10 & 1.3 & 143 & 73 & 28 \\
\hline 26 & 22 & 2 & .12 & 268 & 270 & 195 & 108 & 12 & 3.5 \\
\hline 27 & 21 & 2 & .11 & 180 & 39 & 19 & 88 & 6 & 1.4 \\
\hline 28 & 32 & 6 & .52 & 140 & 18 & 6.8 & 74 & 5 & 1.0 \\
\hline 29 & 28 & 7 & .53 & 106 & 12 & 3.4 & 64 & 4 & .69 \\
\hline 30 & 23 & 2 & .12 & 82 & 8 & 1.8 & 55 & 3 & .45 \\
\hline 31 & 21 & 1 & .06 & -- & -- & --- & 49 & 3 & .40 \\
\hline Total & 1854 & -- & 105.10 & 1771 & -- & 241.44 & 1565 & --- & 51.60 \\
\hline
\end{tabular}


Table 3.--Daily mean water-weighted concentrations and discharges--continued

03033225 East Branch Mahoning Creek near Big Run, Pa.--continued

Sediment discharge, suspended (tons/day), water year October 1979 to September 1980--continued

\begin{tabular}{|c|c|c|c|c|c|c|c|c|c|}
\hline Day & $\begin{array}{c}\text { Mean } \\
\text { discharge } \\
\left(\mathrm{ft}^{3} / \mathrm{s}\right)\end{array}$ & $\begin{array}{l}\text { Mean } \\
\text { concen- } \\
\text { tration } \\
(\mathrm{mg} / \mathrm{L})\end{array}$ & $\begin{array}{l}\text { Sediment } \\
\text { discharge } \\
\text { (tons/day) }\end{array}$ & $\begin{array}{c}\text { Mean } \\
\text { discharge } \\
\left(\mathrm{ft}^{3} / \mathrm{s}\right)\end{array}$ & $\begin{array}{l}\text { Mean } \\
\text { concen- } \\
\text { tration } \\
(\mathrm{mg} / \mathrm{L})\end{array}$ & $\begin{array}{l}\text { Sediment } \\
\text { discharge } \\
\text { (tons/day) }\end{array}$ & $\begin{array}{c}\text { Mean } \\
\text { discharge } \\
\left(\mathrm{ft}^{3} / \mathrm{s}\right) \\
\end{array}$ & $\begin{array}{l}\text { Mean } \\
\text { concen- } \\
\text { tration } \\
(\mathrm{mg} / \mathrm{L})\end{array}$ & $\begin{array}{l}\text { Sediment } \\
\text { discharge } \\
\text { (tons/day) }\end{array}$ \\
\hline
\end{tabular}

January

February

March

(tons/day)

\begin{tabular}{|c|c|c|c|c|c|c|c|c|}
\hline 44 & 4 & 0.48 & 19 & 3 & 0.15 & 32 & 9 & 0.78 \\
\hline 38 & 3 & .31 & 18 & 3 & .15 & 31 & 6 & .50 \\
\hline 34 & 3 & .28 & 18 & 3 & .15 & 31 & 5 & .42 \\
\hline 31 & 3 & .25 & 17 & 2 & .09 & 30 & 5 & .41 \\
\hline 29 & 3 & .23 & 16 & 5 & .22 & 79 & 61 & 13 \\
\hline 27 & 2 & .15 & 15 & 4 & .16 & 121 & 131 & 43 \\
\hline 26 & 2 & .14 & 15 & 6 & .24 & 59 & 45 & 7.2 \\
\hline 24 & 2 & .13 & 14 & 5 & .19 & 335 & 472 & 427 \\
\hline 23 & 2 & .12 & 14 & 4 & .15 & 194 & 111 & 58 \\
\hline 22 & 2 & .12 & 13 & 4 & .14 & 114 & 35 & 11 \\
\hline 28 & 8 & .60 & 13 & 3 & .11 & 113 & 38 & 12 \\
\hline 92 & 94 & 23 & 13 & 5 & .18 & 83 & 30 & 6.7 \\
\hline 69 & 38 & 7.1 & 13 & 4 & .14 & 70 & 22 & 4.2 \\
\hline 75 & 38 & 7.7 & 12 & 3 & .10 & 69 & 18 & 3.4 \\
\hline 71 & 37 & 7.1 & 13 & 3 & .11 & 52 & 18 & 2.5 \\
\hline 55 & 16 & 2.4 & 13 & 3 & .11 & 51 & 11 & 1.5 \\
\hline 45 & 7 & .85 & 13 & 5 & .18 & 123 & 185 & 61 \\
\hline 38 & 6 & .62 & 13 & 5 & .18 & 211 & 222 & 126 \\
\hline 35 & 6 & .57 & 12 & 4 & .13 & 134 & 26 & 9.4 \\
\hline 31 & 4 & .33 & 12 & 3 & .10 & 117 & 14 & 4.4 \\
\hline 29 & 5 & .39 & 16 & 18 & .78 & 147 & 77 & 31 \\
\hline 28 & 4 & .30 & 143 & 66 & 25 & 136 & 52 & 19 \\
\hline 28 & 4 & .30 & 123 & 78 & 26 & 112 & 12 & 3.6 \\
\hline 26 & 3 & .21 & 66 & 14 & 2.5 & 116 & 21 & 6.6 \\
\hline 25 & 4 & .27 & 52 & 5 & .70 & 119 & 26 & 8.4 \\
\hline 25 & 3 & .20 & 42 & 4 & .45 & 94 & 14 & 3.6 \\
\hline 23 & 5 & .31 & 38 & 3 & .31 & 80 & 14 & 3.0 \\
\hline 22 & 4 & .24 & 35 & 3 & .28 & 74 & 18 & 3.6 \\
\hline 21 & 3 & .17 & 34 & 3 & .28 & 221 & 246 & 147 \\
\hline 20 & 3 & .16 & -- & -- & --- & 163 & 27 & 12 \\
\hline 19 & 3 & .15 & --- & -- & --- & 320 & 257 & 222 \\
\hline 103 & --- & 55.18 & 835 & --- & 59.28 & 3631 & --- & 1252.21 \\
\hline
\end{tabular}


Table 3.--Daily mean water-weighted concentrations and discharges--continued

03033225 East Branch Mahoning Creek near Big Run, Pa.--continued

Sediment discharge, suspended (tons/day), water year October 1979 to September 1980--continued

\begin{tabular}{|c|c|c|c|c|c|c|c|c|c|}
\hline Day & $\begin{array}{l}\text { Mean } \\
\text { discharge } \\
\left(\mathrm{ft}^{3} / \mathrm{s}\right)\end{array}$ & $\begin{array}{l}\text { Mean } \\
\text { concen- } \\
\text { tration } \\
(\mathrm{mg} / \mathrm{L})\end{array}$ & $\begin{array}{l}\text { Sediment } \\
\text { discharge } \\
\text { (tons/day) }\end{array}$ & $\begin{array}{c}\text { Mean } \\
\text { discharge } \\
(\mathrm{ft} / \mathrm{s})\end{array}$ & $\begin{array}{l}\text { Mean } \\
\text { concen- } \\
\text { tration } \\
(\mathrm{mg} / \mathrm{L})\end{array}$ & $\begin{array}{l}\text { Sediment } \\
\text { discharge } \\
\text { (tons/day) }\end{array}$ & $\begin{array}{c}\text { Mean } \\
\text { discharge } \\
\left(\mathrm{ft}^{3} / \mathrm{s}\right)\end{array}$ & $\begin{array}{l}\text { Mean } \\
\text { concen- } \\
\text { tration } \\
(\mathrm{mg} / \mathrm{L})\end{array}$ & $\begin{array}{l}\text { Sediment } \\
\text { discharge } \\
\text { (tons/day) }\end{array}$ \\
\hline & & Apri1 & & & May & & & June & \\
\hline 1 & 260 & 81 & 57 & 59 & 7 & 1.1 & 25 & 13 & 0.88 \\
\hline 2 & 184 & 52 & 26 & 53 & 8 & 1.1 & 24 & 13 & .84 \\
\hline 3 & 142 & 31 & 12 & 58 & 10 & 1.6 & 29 & 27 & 2.1 \\
\hline 4 & 135 & 34 & 12 & 48 & 13 & 1.7 & 26 & 21 & 1.5 \\
\hline 5 & 113 & 31 & 9.5 & 43 & 10 & 1.2 & 18 & 8 & .39 \\
\hline 6 & 94 & 27 & 6.9 & 40 & 7 & .76 & 16 & 4 & .17 \\
\hline 7 & 80 & 24 & 5.2 & 37 & 5 & .50 & 17 & 29 & 1.3 \\
\hline 8 & 82 & 39 & 8.6 & 33 & 5 & .45 & 139 & 712 & 267 \\
\hline 9 & 306 & 306 & 253 & 30 & 9 & .73 & 74 & 44 & 8.8 \\
\hline 10 & 188 & 42 & 21 & 28 & 8 & .60 & 88 & 82 & 19 \\
\hline 11 & 146 & 23 & 9.1 & 31 & 8 & .67 & 57 & 24 & 3.7 \\
\hline 12 & 126 & 20 & 6.8 & 215 & 444 & 258 & 46 & 7 & .87 \\
\hline 13 & 115 & 24 & 7.5 & 191 & 57 & 29 & 38 & 7 & .72 \\
\hline 14 & 146 & 48 & 19 & 198 & 173 & 92 & 32 & 8 & .69 \\
\hline 15 & 171 & 54 & 25 & 143 & 23 & 8.9 & 30 & 8 & .65 \\
\hline 16 & 138 & 21 & 7.8 & 113 & 15 & 4.6 & 37 & 31 & 3.1 \\
\hline 17 & 114 & 14 & 4.3 & 89 & 15 & 3.6 & 25 & 11 & .74 \\
\hline 18 & 96 & 14 & 3.6 & 98 & 14 & 3.7 & 20 & 9 & .49 \\
\hline 19 & 80 & 13 & 2.8 & 78 & 8 & 1.7 & 17 & 9 & .41 \\
\hline 20 & 68 & 10 & 1.8 & 65 & 7 & 1.2 & 20 & 10 & .54 \\
\hline 21 & 57 & 8 & 1.2 & 69 & 9 & 1.7 & 16 & 6 & .26 \\
\hline 22 & 49 & 8 & 1.1 & 56 & 7 & 1.1 & 14 & 6 & .23 \\
\hline 23 & 44 & 9 & 1.1 & 46 & 6 & .75 & 12 & 5 & .16 \\
\hline 24 & 39 & 11 & 1.2 & 41 & 6 & .66 & 12 & 5 & .16 \\
\hline 25 & 37 & 8 & .80 & 37 & 5 & .50 & 11 & 6 & .18 \\
\hline 26 & 33 & 6 & .53 & 30 & 4 & .32 & 10 & 6 & .16 \\
\hline 27 & 33 & 9 & .80 & 26 & 4 & .28 & 9.8 & 5 & .13 \\
\hline 28 & 49 & 34 & 4.5 & 24 & 4 & .26 & 9.0 & 6 & .15 \\
\hline 29 & 87 & 61 & 14 & 21 & 3 & .17 & 10 & 8 & .22 \\
\hline 30 & 67 & 12 & 2.2 & 21 & 4 & .23 & 13 & 12 & .42 \\
\hline 31 & -- & -- & - & 25 & 18 & 1.2 & -- & -- & -- \\
\hline Total & 3279 & --- & 526.33 & 2046 & --- & 420.28 & 894.8 & --- & 315.96 \\
\hline
\end{tabular}


The frequency distributions of suspended-sediment concentrations for East Branch Mahoning Creek and several other basins in Pennsylvania are listed in table 4. The table shows that sediment concentrations in the streamflow were $10 \mathrm{mg} / \mathrm{L}$ or less 60 percent of the time, indicating nearly sediment-free streamflow. Beaver Run near Troutville had concentrations less than or equal to $10 \mathrm{mg} / \mathrm{L}$ for 72 percent of the time. Pequea Creek, a predominantly agricultural basin in southeast Pennsylvania, has concentrations less than $10 \mathrm{mg} / \mathrm{L}$ only 2 percent of the time. This stream is always turbid (Ward and Eckhardt, 1979). The comparison of these stations shows the magnitude of the sediment concentrations in the East Branch Mahoning Creek is at a moderate level most of the time.

\section{SEDIMENT YIELDS}

Table 5 summarizes the average annual sediment yield and related land use and soil characteristics of nine basins in Pennsylvania. The validity of these comparisons may be somewhat questionable because of short periods of record used; however, the general magnitude of the annual suspended load figures is indicative of the moderate sediment production in the East Branch Mahoning Creek basin for the first year of sampling. Four of these stations have been selected for closer comparison.

Driftwood Branch Sinnemahoning Creek lies in an area of the Appalachian high plateau with low sediment yield. Figure 9 shows a comparison of the sediment transport curves for this site and the East Branch Mahoning Creek. Higher base flow in the Mahoning Creek contributed to the higher annual yield from the basin; however, sediment discharges were higher throughout the range of water discharge. The soils in the Driftwood Branch Sinnemahoning Creek basin are much less erodible than the soils of the study area, which partly accounts for the lower yields of the Driftwood basin.

The sediment transport curves for Marsh Creek and East Branch Mahoning Creek are shown in figure 10. The figure shows the transport curves to be nearly corresponding. These basins are similar in drainage area and percent land use; Marsh Creek basin, however, contains no strip mining. The soil type $K$ values show that the soils in the East Branch Mahoning Creek basin are more easily eroded than soils in the Marsh Creek basin. Thus, the soils again probably account for the higher sediment yield in the East Branch basin.

The sediment transport curves for Wilson Creek and East Branch Mahoning Creek also correspond (fig. 11). The Wilson Creek basin has considerably more farmland than the East Branch Mahoning Creek basin, but there is no strip mining. The soil types for both basins are similar. The annual yield at Wilson Creek (table 5) was influenced by several large storms producing very high sediment loads during the period of record.

The sediment transport curves for Pequea Creek, an agricultural basin in southeast Pennsylvania, and East Branch Mahoning Creek were also compared (fig. 12). The yields from Pequea Creek are obviously much higher than those from East Branch Mahoning Creek. Since the soil types and $K$ values for both basins are similar, the difference in sediment yield is attributed to different land uses. 
Table 4.--Frequency distribution of suspended-sediment concentrations of selected streams in Pennsylvania

\begin{tabular}{|c|c|c|c|c|c|c|c|c|c|c|c|c|c|c|}
\hline \multirow[b]{2}{*}{ Site } & \multirow{2}{*}{$\begin{array}{l}\text { Years } \\
\text { of } \\
\text { Record }\end{array}$} & \multicolumn{13}{|c|}{$\begin{array}{c}\text { Mean daily concentration, in milligrams per liter, } \\
\text { that was equalled or exceeded for indicated } \\
\text { percentage of time }\end{array}$} \\
\hline & & 2 & 5 & 10 & 20 & 30 & 40 & 50 & 60 & 70 & 80 & 90 & 95 & 98 \\
\hline $\begin{array}{l}\text { East Branch Mahoning Creek } \\
\text { near Big Run }\end{array}$ & $1979-80$ & 180 & 83 & 41 & 22 & 14 & 10 & 8 & 7 & 6 & 4 & 3 & 2 & 2 \\
\hline $\begin{array}{l}\text { Stony Fork near } \\
\text { E11iottsville }\end{array}$ & $1978-79$ & 210 & 140 & 81 & 35 & 23 & 17 & 12 & 10 & 8 & 5 & 2 & 4 & 3 \\
\hline Wilson Creek near Antrim & $1978-79$ & 84 & 38 & 16 & 7 & 5 & 4 & 4 & 3 & 3 & 2 & & 1 & 1 \\
\hline Bixler Run near Loysville & $1954-71$ & 110 & 45 & 25 & 14 & 11 & 8 & 7 & 6 & 5 & 4 & & 2 & 1 \\
\hline $\begin{array}{l}\text { Pequea Creek near Martic } \\
\text { Forge }\end{array}$ & $1977-79$ & 2700 & 1400 & 370 & 89 & 64 & 50 & 40 & 33 & 27 & 20 & 16 & 13 & 9 \\
\hline
\end{tabular}


Table 5.--Summary of average annual sediment yields at selected sites in Pennsylvania (Sites are listed in order of sediment yield)

\begin{tabular}{|c|c|c|c|c|c|c|c|}
\hline & Drainage & Years & & Land use & & & Average \\
\hline Basin & $\begin{array}{l}\text { area } \\
\left(m i^{2}\right)\end{array}$ & $\begin{array}{l}\text { of } \\
\text { record }\end{array}$ & Forested & $\begin{array}{l}\text { Farmland } \\
\text { (percent) }\end{array}$ & Other & $\begin{array}{l}\text { Soil type } \\
K \text { values }\end{array}$ & $\begin{array}{l}\text { annual yield } \\
{\left[\left(\text { tons/mi } / \mathrm{m}^{2}\right) / \mathrm{yr}\right]}\end{array}$ \\
\hline Bixler Runa/ & 15.0 & $1954-71$ & 52 & 45 & 3 & 0.22 & 64 \\
\hline Driftwood Branch & & & & & & & \\
\hline Sinnemahoning Creek & 272.0 & $1963-68$ & 96 & 3 & 1 & .23 & 66 \\
\hline Pine Creekㄷ/ & 604.0 & $1956-70$ & 75 & 23 & 2 & .26 & 75 \\
\hline Marsh Creekㄷ/ & 44.1 & $1955-58$ & 59 & 40 & 1 & .22 & 91 \\
\hline Fishing Creekㄷ/ & 274.0 & $1966-69$ & 54 & 42 & 4 & .23 & 97 \\
\hline East Branch & & & & & & & \\
\hline Mahoning Creek & 29.6 & $1979-80$ & 60 & 35 & 5 & .28 & 121 \\
\hline Wilson Creek & 12.6 & $1978-79$ & 25 & 70 & 5 & .26 & 189 \\
\hline Stony Fork & 7.44 & $1977-79$ & 60 & 40 & - & .28 & 248 \\
\hline Pequea Creekb/ & 148.0 & $1977-79$ & 19 & 79 & 2 & .27 & 1950 \\
\hline $\begin{array}{l}\text { a/Reed (1976) } \\
\underline{b} / \text { Ward and Eckhardt } \\
\text { c/Williams and Reed }\end{array}$ & $\begin{array}{l}\text { (979) } \\
(972)\end{array}$ & & & & & & \\
\hline
\end{tabular}




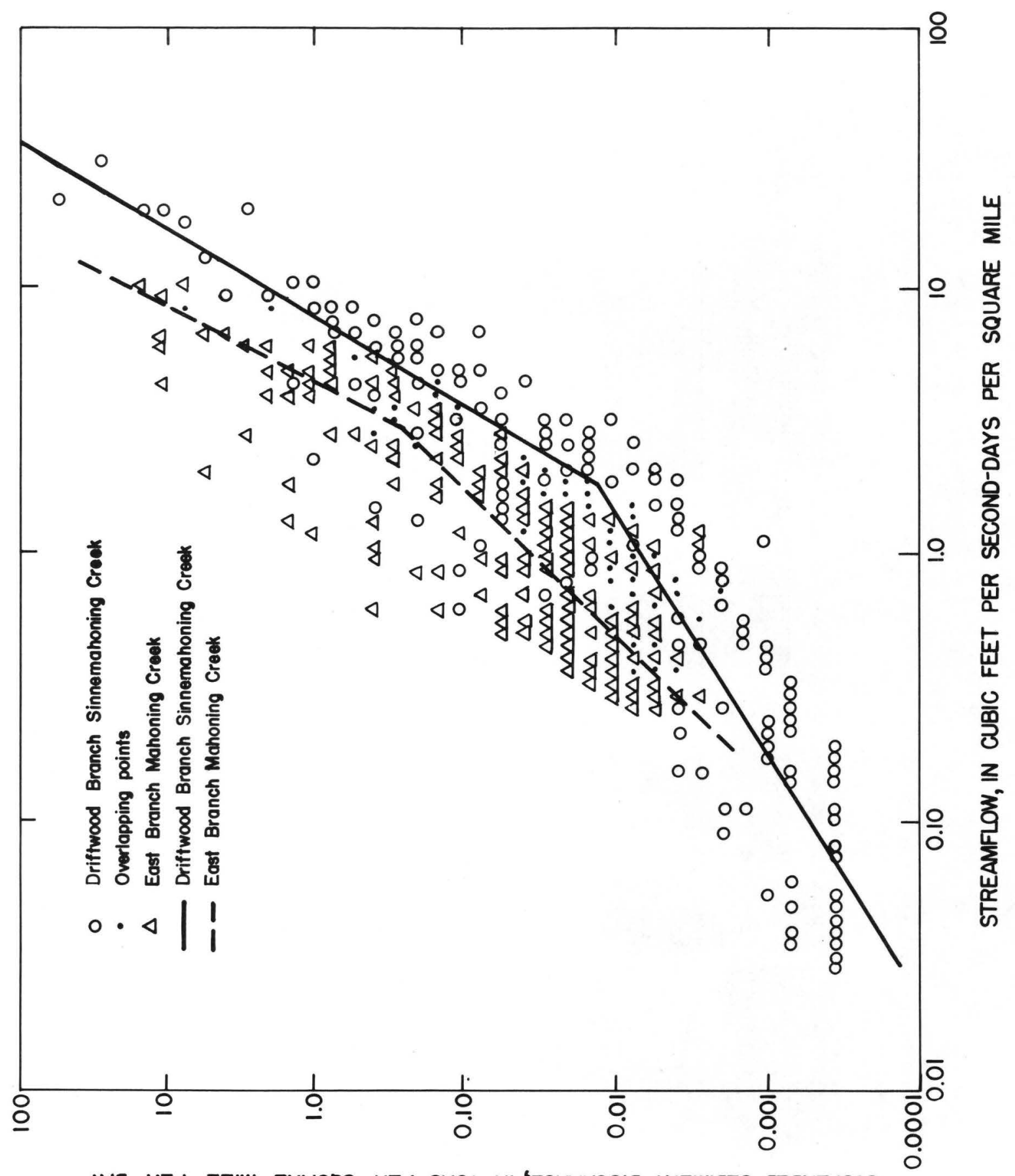

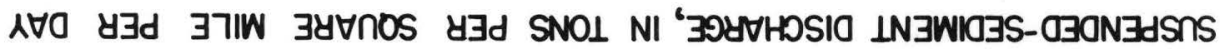

Figure 9.--Comparison of sediment-transport curves for Driftwood Branch Sinnemahoning and East Branch Mahoning Creeks. 


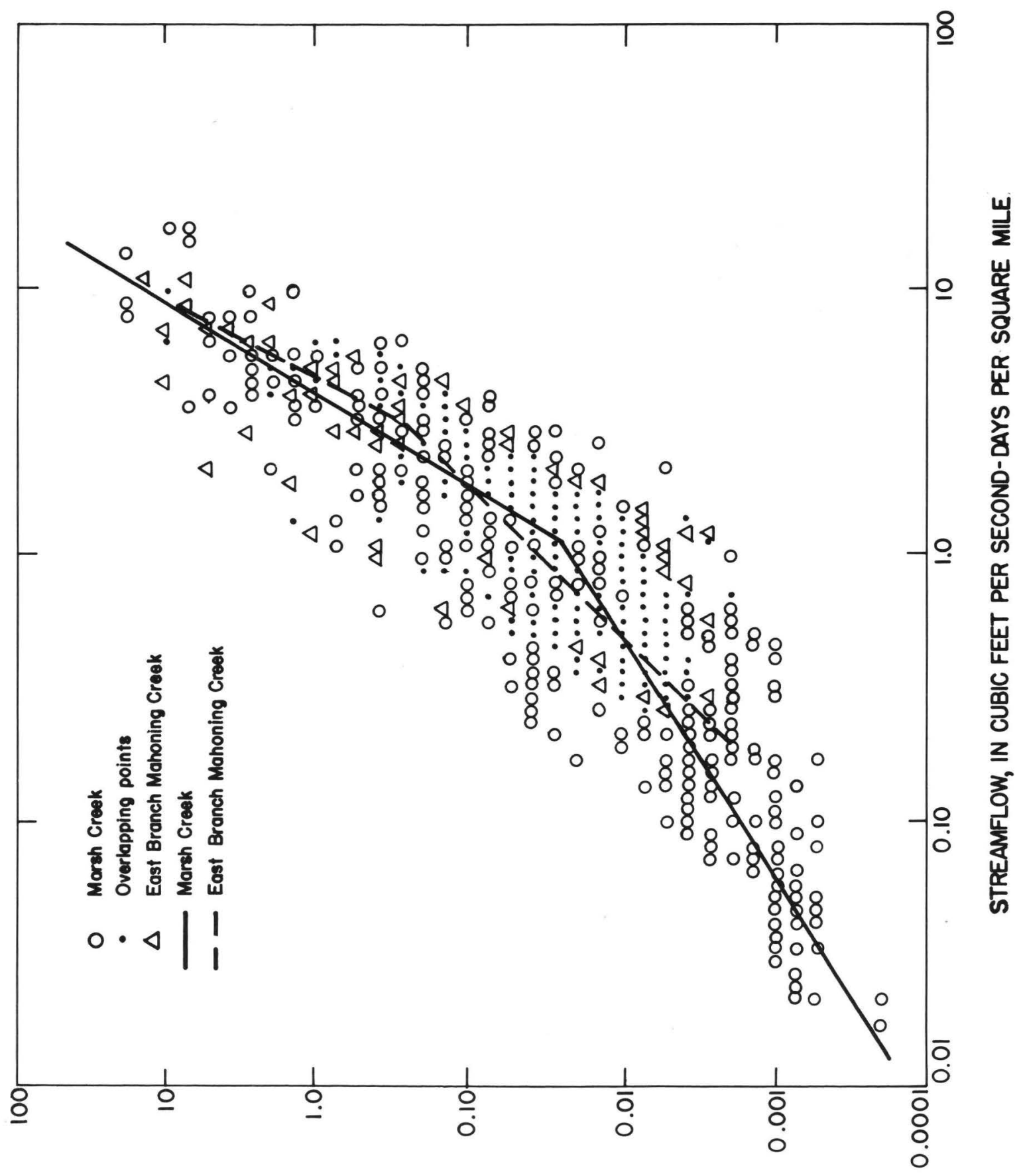

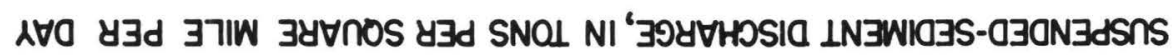

Figure 10.--Comparison of sediment-transport curves for Marsh and East Branch Mahoning Creeks. 


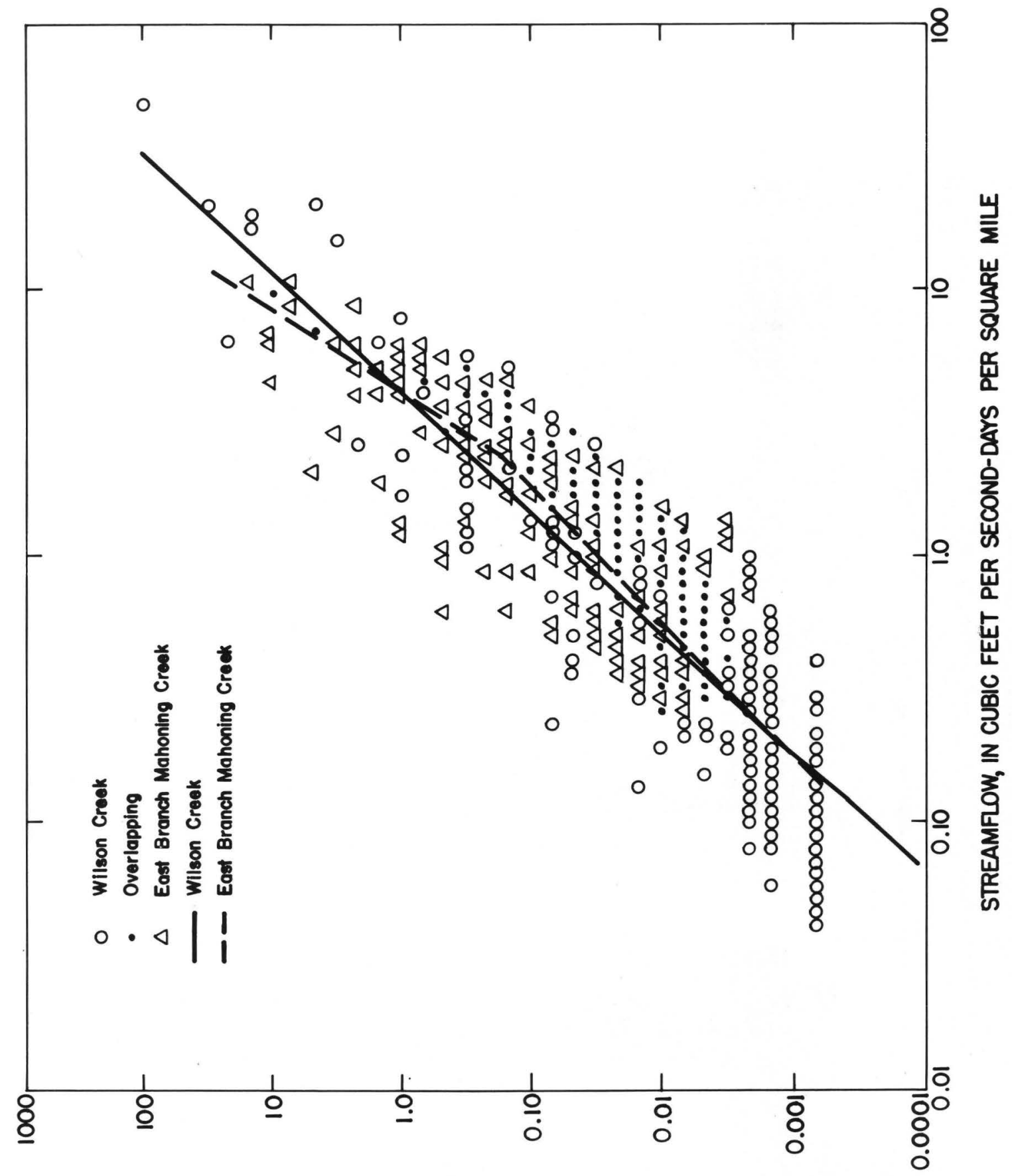

수

Figure 11.--Comparison of sediment-transport curves for Wilson and East Branch Mahoning Creeks. 


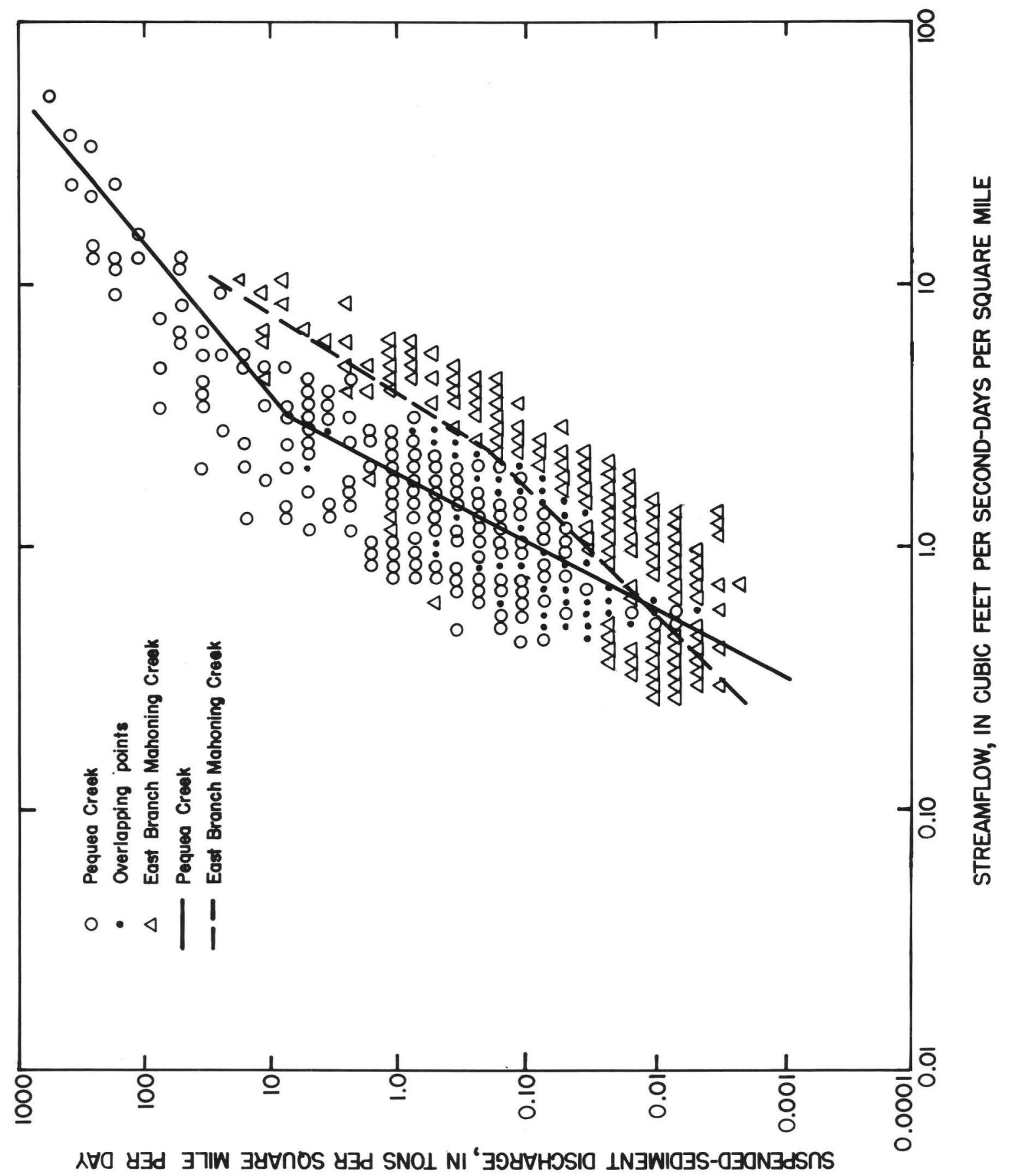

Figure 12.--Comparison of sediment-transport curves for Pequea and East Branch Mahoning Creeks. 
By comparing the sediment transport curves from these stations, it seems that sediment yields in East Branch Mahoning Creek basin fall within the range of yields for basins with similar amounts of farmland. There is no indication that surface mining activities have added substantially to the sediment load transported from the basin.

\section{SUMMARY AND CONCLUSIONS}

The U.S. Geological Survey, in cooperation with the Bureau of Mining and Reclamation (BMR), Pennsylvania Department of Environmental Resources, investigated sediment discharges in the East Branch Mahoning Creek basin in west-central Pennsylvania. The 29.6 square mile basin has a number of maninduced sources of sediment to streams including farming, logging operations, unpaved haul roads, eroding reclaimed areas, and surface mining.

Two stream-gaging stations equipped with automatic pumping samplers were operated. Site 1, East Branch Mahoning Creek near Big Run, began operation in June 1979; and site 2, Beaver Run near Troutville, in December 1979. Samples were analyzed for suspended sediment; these data were used to calculate daily mean concentrations and discharges. In addition to the stream-gaging stations, two precipitation stations were installed.

Regression analyses were run on the daily mean suspended-sediment concentrations and turbidity and showed a good degree of correlation. In the absence of a sediment-measurement program, turbidity data could be used to obtain an approximation of suspended-sediment discharge. However, the relations may be unique and should not be used for other basins without first establishing a correlation.

During most storms in late spring and summer, a sharp rise in streamflow was accompanied by a sudden change in the measured constituents. At the end of a storm, suspended-sediment concentrations and turbidity quickly returned to base-flow levels. Specific conductance returned to base-flow levels more slowly.

During the first year of data collection, 3,570 tons of sediment was transported from the East Branch Mahoning Creek basin. This was an average yield of 121 (tons/mi ${ }^{2}$ )/yr. From December 1979 to June 1980, Beaver Run near Troutville discharged 328 tons of sediment which was 12 percent of the sediment load transported from the entire basin. Sediment concentrations were equal to or less than $10 \mathrm{mg} / \mathrm{L}$ for 60 percent of the time, indicating that streamflow was nearly sediment free most of the time.

By comparing sediment transport curves from several stations in Pennsylvania, it seems that sediment yields in the East Branch Mahoning Creek basin fall within the range of yields for basins with similar amounts of farmland. There is no indication that surface mining activities have added substantially to the sediment load transported from the basin. 
Brown, W. M., III, and Ritter, J. R., 1971, Sediment transport and turbidity in the Eel River basin, California: U.S. Geological Survey Water-Supply Paper 1986, 70 p.

Carter, R. W., and Davidian, Jacob, 1968, General procedure for gaging streams: U.S. Geological Survey Techniques of Water-Resources Investigations, Book 3, Chapter A6, 13 p.

Guy, H. P., 1969, Laboratory theory and methods for sediment analysis: U.S. Geological Survey Techniques of Water-Resources Investigations, Book 5, Chapter $\mathrm{Cl}, 58 \mathrm{p}$.

Guy, H. P., and Norman, V. W., 1970, Field methods for measurement of fluvial sediment: U.S. Geological Survey Techniques of Water-Resources Investigations, Book 3, Chapter C2, 59 p.

Pennsylvania Department of the Environmental Resources, 1980, The State Water Plan: Subbasin 17, Central Alleghany River, 171 p.

Porterfield, George, 1972, Computation of fluvial-sediment discharge: U.S. Geological Survey Techniques of Water-Resources Investigations, Book 3, Chapter C3, 66 p.

Reed, L. A., 1976, Hydrology and sedimentation of Bixler Run basin, central Pennsylvania: U.S. Geological Survey Water-Supply Paper 1798-N, 20 p.

U.S. Department of Agriculture, 1964, Soil Survey, Jefferson County, Pennsylvania: Pennsylvania Soil Conservation Service Report, Ser. 1960, No. 19, 92 p.

---1972, Genera1 soil map - Pennsylvania: scale 1:750,000.

Ward, J. R., and Eckhardt, D. A., 1979, Nonpoint-source discharges in Pequea Creek basin, Pennsylvania, 1977: U.S. Geological Survey Water-Resources Investigations 79-88, $110 \mathrm{p}$.

Williams, K. F., and Reed, L. A., 1972, Appraisal of stream sedimentation in the Susquehanna River basin: U.S. Geological Survey Water-Supply Paper 1532-F, 29 p. 


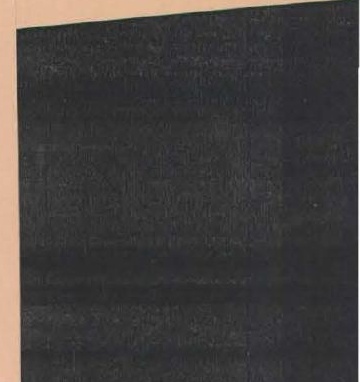

